\title{
Characterising pigments on 30000 -year-old portable art from Apollo 11 Cave, Karas Region, southern Namibia
}

\author{
Riaan F. Rifkin ${ }^{a}$, Linda C. Prinsloo ${ }^{b, c}$, Laure Dayet ${ }^{d}$, Magnus M. Haaland ${ }^{e}$, Christopher S. \\ Henshilwood ${ }^{\mathrm{a}, \mathrm{e}}$, Enrique Lozano Diz $^{\mathrm{f}}$, Stanley Moyo ${ }^{\mathrm{g}}$, Ralf Vogelsang ${ }^{\mathrm{h}}$, Fousy Kambombo ${ }^{\mathrm{i}}$ \\ a Evolutionary Studies Institute, University of the Witwatersrand Wits, Private Bag 3, 2050, South Africa \\ ${ }^{b}$ Department of Physics, University of Pretoria, Private Bag X20, Hatfield 0028, South Africa \\ ${ }^{c}$ Centre for Archaeological Science, School of Earth and Environmental Sciences, University of Wollongong, \\ Wollongong, NSW 2522, Australia \\ ${ }^{d}$ French Institute of South Africa (IFAS), 62 Juta Street, Braamfontein, Johannesburg, South Africa \\ e Institute for Archaeology, History, Culture and Religion, University of Bergen, Øysteinsgate 3, 5007 Bergen, \\ Norway \\ ${ }^{\mathrm{f}}$ ELoDiz Spectroscopy Services, Oxford Road, HP143SX Stokenchurch, United Kingdom \\ ${ }^{g}$ School of Chemistry, University of the Witwatersrand Wits, Private Bag 3, 2050, South Africa \\ ${ }^{h}$ Institute of Prehistory and Early History, University of Cologne, Weyertal 125, Cologne 50923, Germany \\ ' Department of Archaeology, National Museum of Namibia, PO Box 1203, Windhoek 9000, Namibia
}

\begin{abstract}
As an unambiguous indication of complex cognitive capacity, representational art presents explicit evidence for modern and symbolic human behaviour. The only examples of African figurative art dating to the Late Pleistocene comprise seven stone plaques recovered from Apollo 11 Cave in the Huns Mountains, southern Namibia. The plaques derive from a single anthropogenic layer dated by radiocarbon $\left({ }^{14} \mathrm{C}\right)$ accelerator mass spectrometry (AMS) and optically simulated luminescence (OSL) methods to c. 30000 years ago. We present the results of digital (CIE) L*a*b* colourimetric and portable energy dispersive X-ray fluorescence (ED-XRF), Raman spectroscopic and Fourier transform infrared reflectance (FTIR) analyses of the pigments present on the plaques. These results provide the earliest direct evidence, in Africa, for the preparation of pigment-based paint-like mixtures and their application to create prehistoric art. Our research shows that in the creation of the depictions on the plaques, the artists used black pigments derived from manganese and charcoal, red pigments likely derived from ocherous shale and white pigments possibly derived from ostrich eggshell. Additionally, these plaques provide unique evidence for the combined use of mineral- and carbon-based pigment 'crayons' during the African Middle Stone Age.
\end{abstract}

Keywords: Middle Stone Age; Apollo 11; Figurative art; Pigments; (CIE) L*a*b*; ED-XRF; FT-IR; Raman

\section{Introduction}

The southern African Middle Stone Age (MSA) has long provided significant information concerning the cultural, behavioural and cognitive evolution of Homo sapiens. Of the 
indicators of cognitive complexity that become prevalent during the MSA, the capacity for symbolic thought, and the use of symbolism to mediate social behaviour, provide definitive indications of behavioural modernity ( Henshilwood and d'Errico, 2011). Given the evidence supporting the model that fully modern human behaviour originated in sub-Saharan Africa ( Henshilwood et al., 2009; Henshilwood et al., 2011; Lombard, 2012 ; Rito et al., 2013), the c. $30 \mathrm{ka}$ age reported for the earliest southern African portable figurative art is not unusual. Early examples of scored ochre come from Pinnacle Point Cave 13B dated to 164 ka (Marean et al., 2007), and Klasies River Cave 1 at 100 ka (d'Errico et al., 2012a). At Blombos Cave, engraved designs on 17 pieces of ochre, some of which are arguably the earliest abstract 'art', have been recovered from levels dated at $100 \mathrm{ka}$ to $72 \mathrm{ka}$ (Henshilwood et al., 2009). A single example of an ochre piece engraved with a cross hatched design was also found at Klein Kliphuis Shelter and is dated at 50 ka (Mackay and Welz, 2008). Geometrically engraved ostrich eggshell fragments have also been recovered from Diepkloof Rock Shelter (Texier et al., 2013), Klipdrift Shelter (Henshilwood et al., 2014) and Apollo 11 Cave (Vogelsang et al., 2010) in levels dated to between $85 \mathrm{ka}$ and $52 \mathrm{ka}$. The apparent final use of abstract geometric decoration occurs during the terminal phases of the MSA Howiesons Poort (HP), at c. $50 \mathrm{ka}$.

Following a hiatus of nearly 20000 years in the occurrence of abstract decoration in southern Africa, the next known occurrence comes from Apollo 11 Cave in southern Namibia where seven portable stone plaques were recovered, four of which bear figurative depictions. These are the earliest known examples of figurative art in Africa, recently redated by radiocarbon $\left({ }^{14} \mathrm{C}\right)$ accelerator mass spectrometry (AMS) and optically stimulated luminescence (OSL) methods to c. 30 ka (Jacobs et al., 2008; Vogelsang et al., 2010; Wendt, 1972; Wendt, 1974 ; Wendt, 1976). Apart from these examples, figurative portable art only reappears in southern Africa after the Last Glacial Maximum (LGM) to become a recurring feature in Later Stone Age (LSA) contexts (see Morris and Beaumont (1994); Pearce (2010); Thackeray et al. (1981)). Given the cultural and evolutionary significance of these artefacts, we present the results of digital $(\mathrm{CIE}) \mathrm{L}^{*} a{ }^{*} b *$ colourimetric and portable energy dispersive $X$-ray fluorescence (ED-XRF), Raman spectroscopic and Fourier transform infrared reflectance (FT-IR) analyses of the pigments present on the plaques.

\section{Apollo 11 Cave}

Apollo 11 is a small $\left(\sim 150 \mathrm{~m}^{2}\right.$ ) cave situated in a limestone cliff face above the upper Nuob River in the Huns Mountains (Succulent Karoo biome), Karas Region, southern Namibia (Fig. 1). Wolfgang Erich Wendt (University of Cologne, Germany) commenced excavations at the site in 1969, dividing the stratigraphic sequence into 5 major units labelled 0 to IV, including several sub-units labelled A to $H$ (Wendt, 1974). In 2007, Vogelsang et al. (2010) divided the sequence into 24 units labelled from A to Z. Trench A was excavated by Wendt in 1969 and includes eleven $1 \mathrm{~m}^{2}$ squares labelled $A 2$ to $A 12$. Four of the plaques, here referred to as AP1, AP3, AP4 and AP5, were recovered from square A9 in August 1969. In 1972, two extensions in square $A 9\left(A 9_{x} 1\right.$ and $\left.A 9_{x} 2\right)$ were excavated to clarify stratigraphic concerns and to establish the positions of the plaques recovered in 1969. Consequently, three further plaques (AP2, AP6 and AP7), one fitting to a fragment from the excavation in August 1969, were recovered in October 1972 (Wendt, 1974 ; Wendt, 1976) (Table 1). 


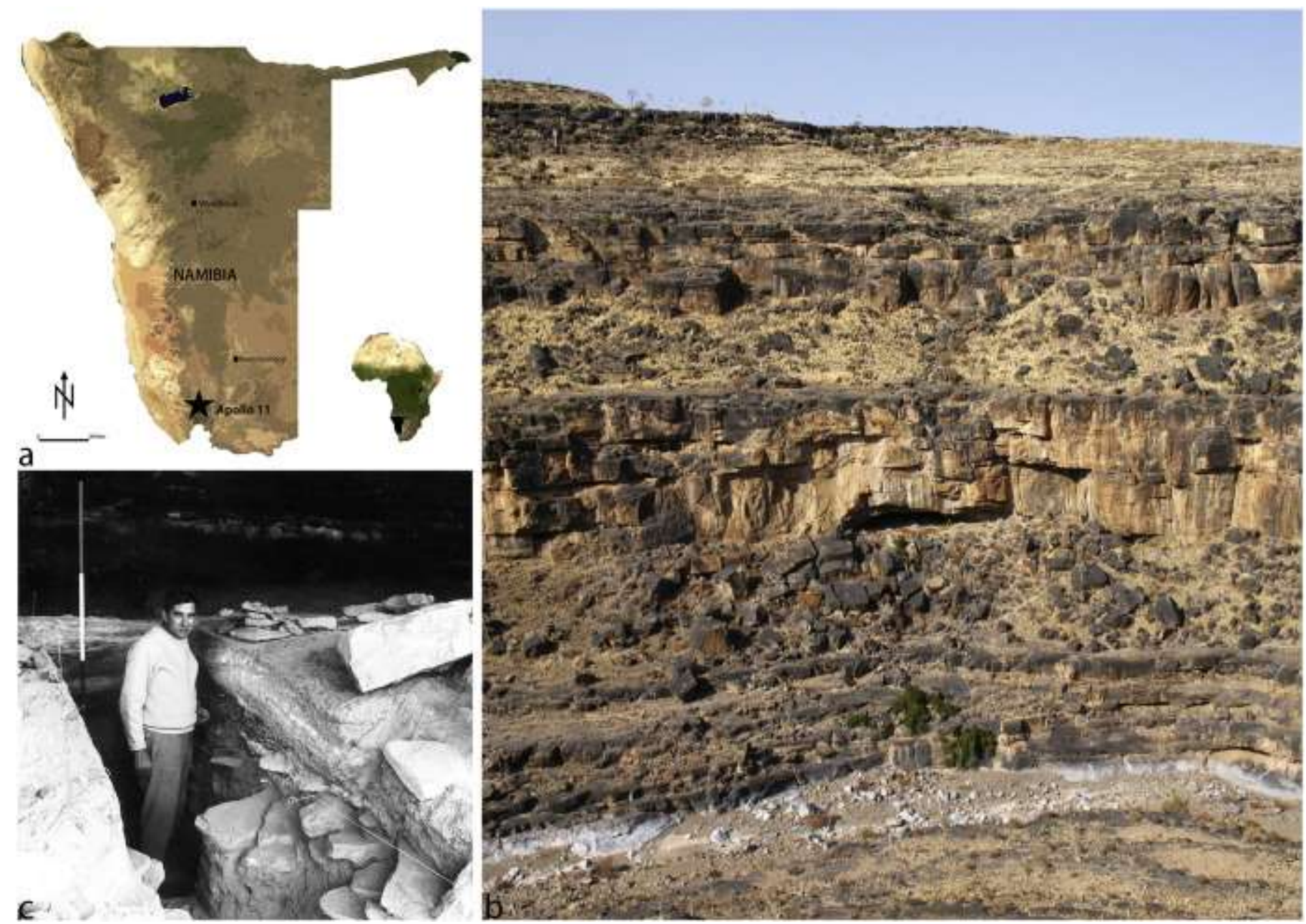

Fig. 1. Apollo 11 Cave is located in the Karas Region of southern Namibia (a) and situated against a limestone cliff on the eastern slope of the Nuob River (b). The site was excavated by W. Erich Wendt (University of Cologne, Germany) in 1969 and 1972 (c) (Photograph courtesy Antje Otto).

Table 1. Inventory of the plaques recovered from Apollo 11 in 1969 and 1972 (dimensions are indicated in mm for breadth, height and width, respectively).

\begin{tabular}{|c|c|c|c|c|c|}
\hline Plaque number & Provenance & Recovered & Geology & Dimensions & Pigment \\
\hline $\begin{array}{l}\text { AP1 (NMN CN 2000- } \\
\text { 2500) Hindquarters }\end{array}$ & $\mathrm{A} 9+10 \mathrm{~cm}$ & 1969 & $\begin{array}{l}\text { Micaceous } \\
\text { shale schist }\end{array}$ & $\begin{array}{l}\text { 64.07, 92.73, } \\
9.11\end{array}$ & $\begin{array}{l}\text { Black red } \\
\text { yellow white }\end{array}$ \\
\hline $\begin{array}{l}\text { AP2 (NMN CN 2000- } \\
\text { 2500) Head and torso }\end{array}$ & $\begin{array}{l}\text { A9 Extension } \\
2+5 \mathrm{~cm}\end{array}$ & 1972 & $\begin{array}{l}\text { Micaceous } \\
\text { shale schist }\end{array}$ & $\begin{array}{l}48.96,89.41 \\
9.12\end{array}$ & $\begin{array}{l}\text { Black white } \\
\text { yellow }\end{array}$ \\
\hline $\begin{array}{c}\text { AP3 (NMN CN 2000- } \\
\text { 2500) Zebra }\end{array}$ & $\mathrm{A} 9+2 \mathrm{~cm}$ & 1969 & $\begin{array}{l}\text { Micaceous } \\
\text { shale schist }\end{array}$ & $\begin{array}{l}80.77,131.24, \\
9.75\end{array}$ & $\begin{array}{l}\text { Black white } \\
\text { yellow }\end{array}$ \\
\hline $\begin{array}{l}\text { AP4 (NMN CN 2000- } \\
\text { 2500) Rhinoceros }\end{array}$ & $A 9+2 \mathrm{~cm}$ & 1969 & $\begin{array}{l}\text { Micaceous } \\
\text { shale schist }\end{array}$ & $\begin{array}{l}\text { 134.89, 107.93, } \\
17.33\end{array}$ & $\begin{array}{l}\text { Black white } \\
\text { orange }\end{array}$ \\
\hline $\begin{array}{l}\text { AP5 (NMN CN 2000- } \\
2500) \text { Unidentified }\end{array}$ & $A 9+2 \mathrm{~cm}$ & 1969 & $\begin{array}{l}\text { Micaceous } \\
\text { shale schist }\end{array}$ & $\begin{array}{l}129.77,96.11 \\
10.09\end{array}$ & $\begin{array}{l}\text { Red black } \\
\text { grey white }\end{array}$ \\
\hline $\begin{array}{c}\text { AP6 (NMN CN 2000- } \\
\text { 2500) Zebra }\end{array}$ & $\begin{array}{l}\text { A9 Extension 1- } \\
5 \mathrm{~cm}\end{array}$ & 1972 & $\begin{array}{l}\text { Micaceous } \\
\text { shale schist }\end{array}$ & $\begin{array}{l}132.05,67.15 \\
7.92\end{array}$ & $\begin{array}{l}\text { Black white } \\
\text { red }\end{array}$ \\
\hline $\begin{array}{l}\text { AP7 (NMN CN 2000- } \\
2500 \text { ) Unidentified }\end{array}$ & $\begin{array}{l}\text { A9 Extension } \\
2+8 \mathrm{~cm}\end{array}$ & 1972 & $\begin{array}{l}\text { Micaceous } \\
\text { shale schist }\end{array}$ & $\begin{array}{l}\text { 140.42, 115.49, } \\
23.27\end{array}$ & $\begin{array}{l}\text { Black white } \\
\text { red orange }\end{array}$ \\
\hline
\end{tabular}


The seven plaques derive from the uppermost horizon of Layer $E$, subsequently labelled Unit $M$ by Vogelsang et al. (2010), at the interface between the final MSA and the earliest LSA levels (Wendt, 1974). Radiocarbon ages of 28 ka to 26 ka were initially reported for these levels (Wendt, 1974 ; Wendt, 1976), with four dates (PTA-1040, KN-I 813, KN-2056 and KN2115 ) indicating a mean age of $28.5 \pm 0.59 \mathrm{ka}$ for the deposits surrounding the plaques. In 2007, a team from the University of Cologne collected eight samples for OSL dating (Jacobs et al., 2008) and subjected 44 samples from the original excavations to AMS dating (Vogelsang et al., 2010). It was determined that the lower LSA has a weighted mean age of $22.3 \pm 0.4 \mathrm{ka}$ and the uppermost MSA a mean age of $29.8 \pm 1.1 \mathrm{ka}$. An AMS date of $29.0 \pm 0.4 \mathrm{BP}(\mathrm{KIA}-35,917)$ and an OSL age of $29.4 \pm 1.4 \mathrm{ka}$ were obtained for the same deposits. Given these ages, and the fact that the uppermost MSA has a weighted mean age of $29.8 \pm 1.1$ years BP, we consider the plaques to be reliably dated to c. $30 \mathrm{ka}$.

Based largely on the perceived combination of animal and human physical characteristics on AP 1 and AP2 (Fig. 2), the Apollo 11 plaques have provided considerable inspiration for discussions concerning prehistoric symbolism and ideology. The depiction of anthropomorphic figures displaying animal physical characteristics (therianthropes) is an attribute widely associated with shamanistic cosmology (Lewis-Williams, 1981) and is pervasive in southern African San rock art. As the primary interpretation of therianthropes relates to shamans and their experiences of altered states of consciousness (Lewis-Williams, 2006), the image has been construed as reminiscent of the ability to both experience and communicate such altered states. The analyses of early LSA artefacts from Border Cave places the emergence of modern hunter-gatherer adaptation at $44 \mathrm{ka}$ (d'Errico et al., 2012b ; Villa et al., 2012), suggesting that, in some regions at least, there might be a degree of technological and cultural continuity between the MSA and the LSA. It is, in light of the interpretation of the AP1 and AP2 imagery as shamanistic, therefore possible that a degree of ideological and cosmological continuity may exist between the MSA and the LSA.

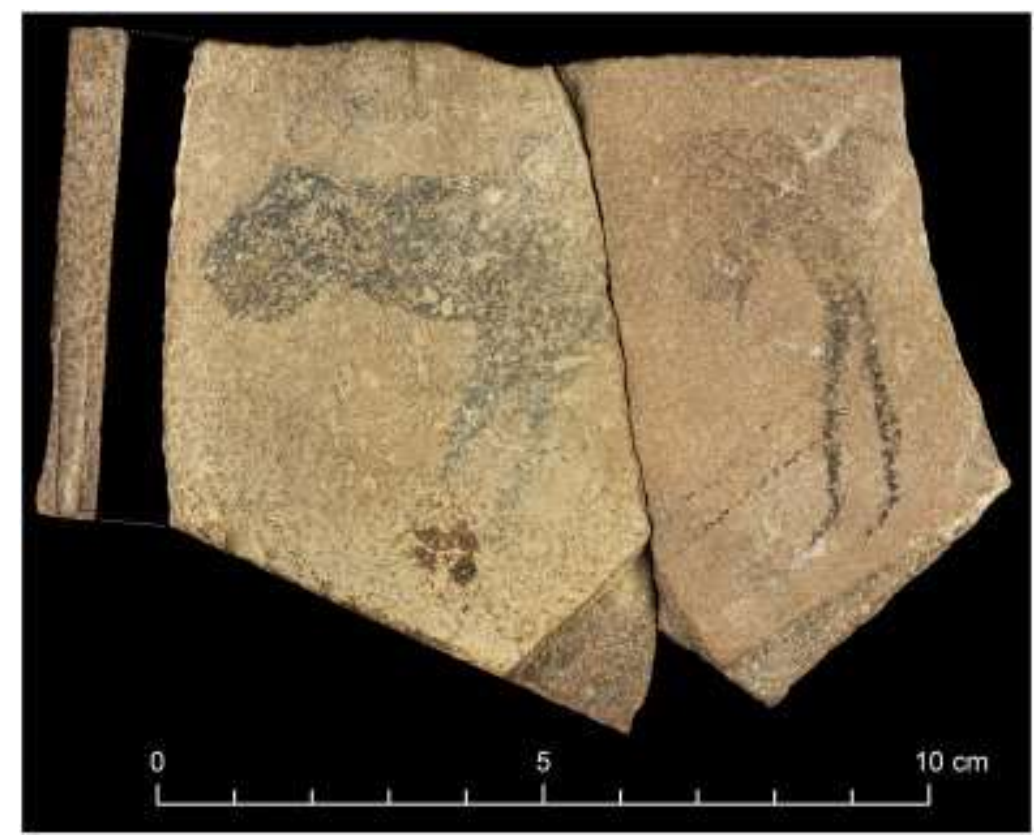

Fig. 2. AP1 (on left) and AP2 (right) were recovered from Apollo 11 in 1969 and 1972, respectively. Colour images of AP3 to AP7 are provided in Online Resource 1. Photographic details of specific features are presented in Online Resource 2. 


\section{Materials and methods}

The plaques are curated by the National Heritage Council of Namibia and the National Museum of Namibia. Analyses were carried out at the National Museum of Namibia in Windhoek. Prior to analyses, dust particles were dislodged with gentle air pressure. Visual observations were made with an Aven ZipScope digital USB microscope at $10 \times$ to $25 \times$ magnification. The plaques were photographed with a 16.2 MP Nikon D4 digital SLR camera fitted with a Nikon $60 \mathrm{~mm}$ AF-S Micro-Nikkor lens. Photo-mosaic images were imported into Nikon Camera Raw 8.6 and their exposure, white balance, sharpness and contrast settings adjusted (Rifkin et al., 2015). Image rendering therefore approximates the plaques to the extent that viable colourimetric ( $\left.\mathrm{CIEL}^{*} \mathrm{a}^{*} \mathrm{~b}^{*}\right)$ measurements can be made from the digital photographs.

In addition to obtaining measurements from the respective rock surface backgrounds of each plaque, we selected 37 pigment-rich points or 'spots' on the 7 plaques for analyses (Fig. 3). Our analytical protocol did not entail the sampling of pigments and we used only non-invasive portable ED-XRF, Raman spectroscopic and FT-IR analytical equipment. Since at least some pigmented areas could derive from post-depositional contact with artefacts and other materials, or as a result of organic taphonomic processes, we selected areas which appeared to a) host the most substantial concentrations of pigment and b) formed part of pigmented regions comprising discernible images or parts of images. Non-pigmented areas were also analysed to facilitate the comparison of pigments and the underlying rock surfaces. The differential results obtained for pigmented and non-pigmented surfaces are central to the identification of deliberately applied pigments.

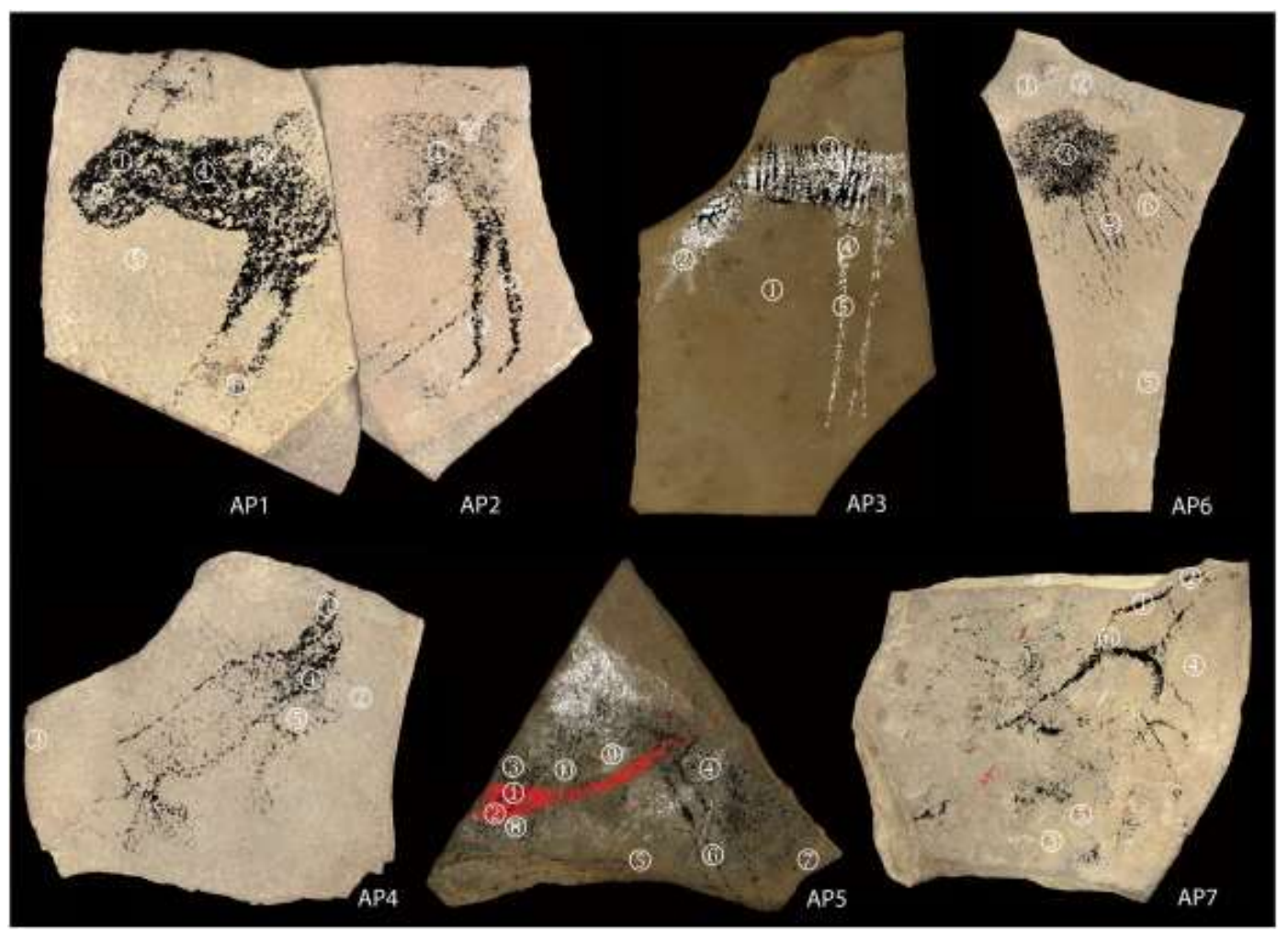

Fig. 3. Areas analysed by digital (CIEL*a*b*) colourimetry and ED-XRF. Selections of the same areas were targeted for FT-IR and Raman analyses. Images shown were digitally enhanced with the DStretch ${ }^{\circledR}$ decorrelation stretch algorithm program (Harman, 2008 ; Rifkin et al., 2015). 


\subsection{Digital colourimetric analyses}

Trichromatic colourimetric coordinates were determined within the Commission International de l'Eclairage (CIE) L*a*b space

(http://www.cie.co.at/index.php/Publications/Standards) in which $L^{*}$ represents brightness $(0=$ black and $100=$ white $), a^{*}$ the red-green chromatic axis $\left(+a^{*}=\right.$ red and $-a^{*}=$ green $)$ and $b^{*}$ the yellow-blue axis $\left(+b^{*}=\right.$ yellow and $-b^{*}=$ blue) (Xu et al., 2012). We used the Adobe Photoshop CS6 'Lab slider option' to obtain $L^{*} a * b *$ values for each area analysed by ED-XRF. This method is gaining increasing applicability in scientific research (Frausto-Reyes et al., 2009 ; León et al., 2006). Colour measurements were obtained from $0.25 \mathrm{~cm}^{2}$ areas which approximate the measurement apertures of most commercially available colourimeters. The $\mathrm{CIE}-2000$ colour difference formula $\left(\Delta \mathrm{E}^{*} 2000\right)$ (http://www.brucelindbloom.com/index.html?ColorDifferenceCalcHelp.html) was used to determine the colour differences between pigments and rock backgrounds.

\subsection{ED-XRF}

We used a Bruker Tracer III SD portable ED-XRF analyser to determine the elemental contents of the pigments on the plaques. The device was fitted with a Peltier cooled Silicon Drift Detector (SDD) with a resolution of $145 \mathrm{keV}$ at $5.9 \mathrm{keV}$, resulting in a rate of 100000 counts per second (cps). Two instrument settings were used. The instrument was configured to operate at $15 \mathrm{keV}$ and $55 \mu \mathrm{A}$ without a filter. A vacuum system was included to remove air from the instrument and to facilitate the detection of low atomic number elements such as Al, Si and Ca. The device was also operated at $40 \mathrm{keV}$ and $10 \mu \mathrm{A}$. Two beam filters, comprising $1 \mathrm{~mm}$ Al and $1 \mathrm{~mm}$ Ti filters, were positioned in the filter slot between the sample and the X-Ray tube. These settings allowed the X-rays from $12 \mathrm{keV}$ to $40 \mathrm{keV}$ to excite elements with higher atomic numbers, specifically Fe and $\mathrm{Mn}$. In both configurations, individual point analyses were performed for $120 \mathrm{~s}$. Acquired data was processed with the Bruker PXRF and ARTAX software programs. We made control measurements on both experimentally pigmented and the actual archaeological rock support surfaces to establish the integrity of the equipment and to develop the optimal analytical procedure.

The XRF data were not obtained in controlled and reproducible conditions. The distance of the instrument from the samples, the surface roughness of the samples and ambient temperature and humidity could, among other factors, not be controlled. In this respect we cannot consider the data as accurate enough for true quantitative treatment. We therefore use the spectra and peak areas as qualitative and semi-quantitative information for a comparison between the rock support surfaces and pigmented surfaces.

\subsection{FT-IR spectroscopy}

Mid-infrared spectra were recorded using a portable Bruker Alpha-R spectrometer with a footprint of $22 \times 33 \mathrm{~cm}^{2}$ and approximate weight of $7 \mathrm{~kg}$. Infrared spectra could be collected without touching the sample by using a QuickSnap Reflection Module with a long working distance of about $2 \mathrm{~cm}$. A video camera made it possible to observe the measured spot, which is circular and which has a diameter of roughly $6 \mathrm{~mm}$. The spectral resolution of the 
instrument is $4 \mathrm{~cm}^{-1}$ and 32 scans were averaged for each interferogram. Spectra were recorded in the range $700-4000 \mathrm{~cm}^{-1}$ and are presented as reflectance spectra.

Table 2. Results for (CIE) L*a*b* colourimetric measurements of $0.25 \mathrm{~cm}^{2}$ on the Apollo 11 plaques. Digitally recorded $L^{*} a^{*} b^{*}$ colour coordinate swatches and results for $\mathrm{CIE}-2000$ colour difference $\left(\Delta \mathrm{E}^{*} 2000\right)$ analyses are indicated. For all plaques, the respective rock supports were selected as the reference.

\begin{tabular}{|c|c|c|c|c|c|c|c|}
\hline Plaque & Spot & Description & $\mathrm{L}^{*}$ & $a^{*}$ & $b^{*}$ & Colour & $\Delta \mathrm{E}^{*}{ }_{2000}$ \\
\hline \multirow[t]{6}{*}{ AP1 } & 5 & Rock support & 72 & 9 & 28 & & - \\
\hline & 1 & Black pigment & 39 & 1 & 5 & & 34.09 \\
\hline & 2 & Red pigment & 68 & 40 & 35 & & 17.69 \\
\hline & 3 & White pigment & 95 & 1 & 18 & & 17.34 \\
\hline & 4 & Black pigment & 40 & 1 & 6 & & 32.77 \\
\hline & 6 & Recent residue & 47 & 8 & 20 & & 22.49 \\
\hline \multirow[t]{6}{*}{ AP2 } & 6 & Rock support & 67 & 10 & 23 & & - \\
\hline & 1 & Black pigment & 34 & 4 & 9 & & 34.13 \\
\hline & 2 & White pigment & 85 & 3 & 14 & & 14.94 \\
\hline & 3 & Red pigment & 68 & 52 & 31 & & 20.77 \\
\hline & 4 & Black pigment & 23 & 2 & 4 & & 43.61 \\
\hline & 5 & Black pigment & 20 & 1 & 3 & & 45.74 \\
\hline \multirow[t]{5}{*}{ AP3 } & 1 & Rock support & 73 & 6 & 22 & & - \\
\hline & 2 & White pigment & 88 & 2 & 15 & & 11.54 \\
\hline & 3 & Black pigment & 41 & 2 & 5 & & 31.33 \\
\hline & 4 & White pigment & 95 & 2 & 10 & & 16.45 \\
\hline & 5 & White pigment & 91 & 2 & 16 & & 13.11 \\
\hline \multirow[t]{5}{*}{ AP4 } & 2 & Rock support & 63 & 6 & 16 & & - \\
\hline & 1 & Black pigment & 8 & 3 & 2 & & 83.62 \\
\hline & 3 & Red pigment & 49 & 24 & 44 & & 18.83 \\
\hline & 4 & Black pigment & 18 & 7 & 10 & & 9.62 \\
\hline & 5 & White pigment & 93 & 1 & 11 & & 85.31 \\
\hline \multirow[t]{10}{*}{ AP5 } & 5 & Rock support & 61 & 8 & 20 & & - \\
\hline & 1 & Red pigment & 30 & 33 & 27 & & 33.07 \\
\hline & 2 & Red pigment & 44 & 44 & 39 & & 24,46 \\
\hline & 3 & Grey pigment & 50 & 2 & 3 & & 21.81 \\
\hline & 4 & White pigment & 91 & 2 & 8 & & 23.37 \\
\hline & 6 & Black pigment & 4 & 0 & 1 & & 48.22 \\
\hline & 7 & Black pigment & 20 & 2 & 2 & & 38.48 \\
\hline & 8 & Grey pigment & 52 & 1 & 4 & & 16.23 \\
\hline & 9 & White pigment & 96 & 1 & 6 & & 26.80 \\
\hline & 10 & Brown pigment & 70 & 5 & 17 & & 7.94 \\
\hline \multirow[t]{6}{*}{ APG } & 5 & Rock support & 59 & 8 & 25 & & - \\
\hline & 1 & Resin or mastic & 67 & 5 & 14 & & 9.02 \\
\hline & 2 & Resin or mastic & 64 & 6 & 15 & & 6.85 \\
\hline & 3 & Organic material & 55 & 6 & 18 & & 5.17 \\
\hline & 4 & Black pigment & 21 & 2 & 6 & & 35.43 \\
\hline & 6 & White pigment & 95 & 1 & 7 & & 28.25 \\
\hline \multirow[t]{6}{*}{ AP7 } & 4 & Rock support & 66 & 10 & 23 & & - \\
\hline & 1 & Black pigment & 25 & 1 & 2 & & 41.83 \\
\hline & 2 & Orange residue & 74 & 23 & 39 & & 10.49 \\
\hline & 3 & Red pigment & 50 & 41 & 21 & & 23.8 \\
\hline & 5 & Red pigment & 65 & 44 & 24 & & 19.3 \\
\hline & 6 & Orange residue & 65 & 19 & 39 & & 7,35 \\
\hline
\end{tabular}




\subsection{Raman spectroscopy}

Raman spectra were recorded with a portable BWTek iRaman Plus 785S instrument equipped with a triggered fibreoptic probe (BAC102). A $785 \mathrm{~nm}$ CleanLaze $^{\mathrm{TM}}$ laser was used as excitation source, with the laser beam focused to an approximately $85 \mu^{2}$ spot. The Raman signal was detected with a 2048-pixel thermoelectrically cooled CCD camera $\left(14{ }^{\circ} \mathrm{C}\right)$ with a spectral resolution of approximately $5 \mathrm{~cm}^{-1}$. The instrument weighs $\sim 3 \mathrm{~kg}$ and measures $17 \times 34 \times 23.4 \mathrm{~cm}$. Several tests were conducted to establish the reliability of the equipment and to ascertain the optimal analytical procedure without touching the samples. We used non-archaeological red ochre and charcoal applied to a geologically similar type of stone for this purpose.

\section{Results}

\subsection{Digital colourimetric analyses}

Digital colour differentiation methods present an increasingly viable alternative to expensive and often unwieldy colour measurement devices (Frausto-Reyes et al., 2009 ; León et al., 2006). Colourimetric analyses indicate negligible to substantial differences ( $\left.\Delta E^{*} 2000\right)$ between underlying rock support structures and pigments (Table 2). Minor differences in colour measurements do occur and are attributed to Adobe Photoshop rounding errors.

Colour measurement $\left(L^{*} a * b *\right)$ values are most pronounced for the white pigments, followed by black and red pigments. The most significant differences in white pigments derive from AP4 $\left(\Delta E^{*} 200085.31\right)$ and AP6 (28.25). Colour difference values $\left(\Delta E^{*} 2000\right)$ of 83.62 were obtained for black pigment on AP4, 48.22 for black on AP5, and 41.83 for black pigments on AP7. Red is most distinguishable on AP5 ( $\triangle E^{*} 200033.07$ and 24.06). The least distinct colour differences occur in the case of brown pigment on AP5 ( $\triangle E * 20007.94)$ and orange residues on AP7 (7.35).

\subsection{X-ray fluorescence (ED-XRF)}

ED-XRF analyses indicate that the micaceous shale schist rock mediums comprise $\mathrm{Al}, \mathrm{Si}, \mathrm{K}, \mathrm{Ca}$ and $\mathrm{Fe}$ as major elements and $\mathrm{Ti}$ and $\mathrm{Mn}$ as minor or trace elements (Table 3). Excitation at $15 \mathrm{keV}$ revealed the presence of $\mathrm{Al}, \mathrm{Si}, \mathrm{K}, \mathrm{Ca}, \mathrm{Ti}, \mathrm{Mn}$ and $\mathrm{Fe}$ and excitation at $40 \mathrm{keV}$ the presence of heavier elements including $\mathrm{Cu}, \mathrm{Zn}, \mathrm{Rb}, \mathrm{Sr}, \mathrm{Y}$ and $\mathrm{Zr}$. The incidence of these elements was not considered significant as no marked differences in signal intensities from rock supports and the pigmented areas were perceived. 
Table 3. Normalised counts for ED-XRF analyses of AP1 to AP7. Measurements for the rock mediums are indicated in italics.

\begin{tabular}{|c|c|c|c|c|c|c|c|c|c|c|c|c|c|c|c|c|}
\hline \multirow[b]{2}{*}{ Plaque } & \multirow{2}{*}{ Spot } & \multirow{2}{*}{$\begin{array}{c}\text { Primary } \\
\text { colour }\end{array}$} & Al & Si & & & & $\mathrm{Mn}$ & $\mathrm{Fe}$ & $\mathrm{Cl}$ & $\mathrm{Cu}$ & & $\mathbf{R b}$ & $\mathrm{Sr}$ & $Y$ & $\mathrm{Zr}$ \\
\hline & & & \multicolumn{7}{|c|}{ Elements detected at $15 \mathrm{keV}$} & \multicolumn{7}{|c|}{ Elements detected at $40 \mathrm{keV}$} \\
\hline \multirow{7}{*}{ AP1 } & 5 & Support & 0.00890 & 0.06130 & 0.05540 & 0.31080 & 0.02470 & 0.01810 & 0.52080 & 0.00000 & 0.00646 & 0.00935 & 0.04249 & 0.06564 & 0.03867 & 0.09122 \\
\hline & 1 & Black & 0.00840 & 0.06120 & 0.05860 & 0.25750 & 0.02750 & 0.01880 & 0.56800 & 0.00567 & 0.00610 & 0.00913 & 0.04180 & 0.06733 & 0.03800 & 0.08989 \\
\hline & 2 & Red & 0.00810 & 0.05970 & 0.05830 & 0.24260 & 0.02860 & 0.01930 & 0.58330 & 0.00549 & 0.00615 & 0.00914 & 0.04053 & 0.05672 & 0.03565 & 0.09479 \\
\hline & 3 & White & 0.00770 & 0.05840 & 0.05540 & 0.23980 & 0.02840 & 0.01990 & 0.59040 & 0.00558 & 0.00633 & 0.00947 & 0.04135 & 0.06408 & 0.03713 & 0.08565 \\
\hline & 4 & Black & 0.00760 & 0.05440 & 0.05390 & 0.26990 & 0.02630 & 0.02030 & 0.56770 & 0.00000 & 0.00632 & 0.00874 & 0.04222 & 0.06193 & 0.03846 & 0.08829 \\
\hline & 6 & Brown & 0.00710 & 0.04070 & 0.05220 & 0.40640 & 0.02170 & 0.01880 & 0.45320 & 0.00000 & 0.00665 & 0.00943 & 0.04057 & 0.05983 & 0.03671 & 0.08808 \\
\hline & 6 & Support & 0.01340 & 0.12420 & 0.06040 & 0.07440 & 0.03620 & 0.01960 & 0.67170 & 0.00486 & 0.00643 & 0.00901 & 0.04018 & 0.04741 & 0.03559 & 0.08696 \\
\hline \multirow{5}{*}{ AP2 } & 1 & Black & 0.01250 & 0.11370 & 0.05990 & 0.06210 & 0.03600 & 0.01970 & 0.69610 & 0.00452 & 0.00664 & 0.00867 & 0.03910 & 0.04679 & 0.03640 & 0.08915 \\
\hline & 2 & White & 0.01260 & 0.10060 & 0.06180 & 0.03980 & 0.03620 & 0.02040 & 0.72850 & 0.00863 & 0.00723 & 0.00894 & 0.04010 & 0.04845 & 0.03634 & 0.09292 \\
\hline & 3 & Red & 0.01260 & 0.11410 & 0.06160 & 0.05910 & 0.03650 & 0.02020 & 0.69590 & 0.00506 & 0.00679 & 0.00883 & 0.04039 & 0.04522 & 0.03719 & 0.08766 \\
\hline & 4 & Black & 0.01170 & 0.10270 & 0.06210 & 0.07530 & 0.03740 & 0.01990 & 0.69090 & 0.00484 & 0.00714 & 0.00919 & 0.04085 & 0.05013 & 0.03669 & 0.09049 \\
\hline & 5 & Black & 0.00980 & 0.08540 & 0.05880 & 0.11180 & 0.03350 & 0.02040 & 0.68030 & 0.00466 & 0.00667 & 0.00876 & 0.04018 & 0.05002 & 0.03689 & 0.08882 \\
\hline \multirow{5}{*}{ AP3 } & 1 & Support & 0.01130 & 0.08090 & 0.05370 & 0.10340 & 0.03010 & 0.01820 & 0.70240 & 0.00484 & 0.00714 & 0.00919 & 0.04085 & 0.05013 & 0.03669 & 0.09049 \\
\hline & 2 & White & 0.01090 & 0.07990 & 0.05400 & 0.13460 & 0.03080 & 0.02090 & 0.66900 & 0.00427 & 0.00941 & 0.00746 & 0.03698 & 0.05212 & 0.03413 & 0.06543 \\
\hline & 3 & Black & 0.00930 & 0.07280 & 0.05010 & 0.08660 & 0.03150 & 0.04270 & 0.70700 & 0.00408 & 0.00947 & 0.00752 & 0.03417 & 0.04612 & 0.03094 & 0.06102 \\
\hline & 4 & White & 0.01110 & 0.09000 & 0.05460 & 0.11060 & 0.03310 & 0.01720 & 0.68330 & 0.00426 & 0.00947 & 0.00740 & 0.03530 & 0.05141 & 0.03269 & 0.06493 \\
\hline & 5 & White & 0.01080 & 0.08320 & 0.05360 & 0.10080 & 0.03280 & 0.01820 & 0.70060 & 0.00408 & 0.00944 & 0.00729 & 0.03481 & 0.04722 & 0.03133 & 0.06350 \\
\hline \multirow{5}{*}{ AP4 } & 2 & Support & 0.00800 & 0.04830 & 0.04700 & 0.35350 & 0.02630 & 0.03550 & 0.48150 & 0.02061 & 0.00470 & 0.00761 & 0.04005 & 0.08472 & 0.04477 & 0.16744 \\
\hline & 1 & Black & 0.00790 & 0.04960 & 0.04580 & 0.33330 & 0.02780 & 0.03650 & 0.49900 & 0.01435 & 0.00445 & 0.00769 & 0.03844 & 0.08459 & 0.04112 & 0.15822 \\
\hline & 3 & Red & 0.00790 & 0.05500 & 0.06070 & 0.33610 & 0.02800 & 0.03220 & 0.48010 & 0.00722 & 0.00498 & 0.00725 & 0.03716 & 0.09005 & 0.03877 & 0.16261 \\
\hline & 4 & Black & 0.00820 & 0.05470 & 0.04700 & 0.31400 & 0.03000 & 0.03590 & 0.51020 & 0.01556 & 0.00492 & 0.00785 & 0.04082 & 0.09413 & 0.04364 & 0.16891 \\
\hline & 5 & White & 0.00880 & 0.04960 & 0.04660 & 0.34400 & 0.02660 & 0.03490 & 0.48960 & 0.04878 & 0.00555 & 0.00787 & 0.04638 & 0.10834 & 0.04976 & 0.19213 \\
\hline \multirow{10}{*}{ AP5 } & 5 & Support & 0.00510 & 0.01940 & 0.05330 & 0.71250 & 0.00930 & 0.02970 & 0.17090 & 0.00970 & 0.00531 & 0.00754 & 0.03904 & 0.07627 & 0.03911 & 0.10914 \\
\hline & 1 & Red & 0.00980 & 0.06920 & 0.06360 & 0.15640 & 0.03310 & 0.09350 & 0.57430 & 0.00868 & 0.00497 & 0.00746 & 0.03535 & 0.07212 & 0.03502 & 0.09625 \\
\hline & 2 & Red & 0.01180 & 0.08380 & 0.07310 & 0.13450 & 0.03360 & 0.10630 & 0.55690 & 0.00926 & 0.00503 & 0.00732 & 0.03730 & 0.07446 & 0.03574 & 0.10087 \\
\hline & 3 & Grey & 0.01210 & 0.08220 & 0.06250 & 0.11930 & 0.04100 & 0.11410 & 0.56880 & 0.00990 & 0.00489 & 0.00783 & 0.03827 & 0.08652 & 0.03758 & 0.10537 \\
\hline & 4 & White & 0.01600 & 0.09950 & 0.08640 & 0.12800 & 0.03810 & 0.05430 & 0.57770 & 0.01041 & 0.00563 & 0.00836 & 0.04229 & 0.07382 & 0.04016 & 0.10897 \\
\hline & 6 & Black & 0.00850 & 0.06040 & 0.06150 & 0.31310 & 0.02560 & 0.05180 & 0.47910 & 0.01179 & 0.00523 & 0.00768 & 0.03958 & 0.08884 & 0.03750 & 0.10290 \\
\hline & 7 & Black & 0.01300 & 0.10350 & 0.06700 & 0.08010 & 0.04240 & 0.07250 & 0.62150 & 0.01911 & 0.00507 & 0.00611 & 0.03675 & 0.12864 & 0.03728 & 0.10555 \\
\hline & 8 & Grey & 0.01260 & 0.09240 & 0.06870 & 0.10530 & 0.03500 & 0.11080 & 0.57520 & 0.01175 & 0.00513 & 0.00766 & 0.03856 & 0.08754 & 0.03650 & 0.10220 \\
\hline & 9 & White & 0.00810 & 0.04990 & 0.05900 & 0.35790 & 0.02900 & 0.09880 & 0.39730 & 0.00990 & 0.00486 & 0.00783 & 0.03826 & 0.07652 & 0.03758 & 0.10437 \\
\hline & 10 & Brown & 0.00910 & 0.06370 & 0.06700 & 0.15550 & 0.03490 & 0.14050 & 0.52930 & 0.01461 & 0.00508 & 0.00731 & 0.03949 & 0.12081 & 0.03880 & 0.11302 \\
\hline \multirow{6}{*}{ AP6 } & 5 & Support & 0.01130 & 0.08470 & 0.05220 & 0.12040 & 0.03010 & 0.01800 & 0.68350 & 0.00428 & 0.00900 & 0.00731 & 0.03551 & 0.04831 & 0.03217 & 0.06503 \\
\hline & 1 & Brown & 0.00740 & 0.04440 & 0.05520 & 0.52960 & 0.01920 & 0.03170 & 0.31250 & 0.00629 & 0.00626 & 0.00805 & 0.04146 & 0.17437 & 0.04056 & 0.10987 \\
\hline & 2 & Brown & 0.00770 & 0.04480 & 0.05760 & 0.52550 & 0.02010 & 0.02290 & 0.32150 & 0.00600 & 0.00667 & 0.00786 & 0.04015 & 0.17314 & 0.03921 & 0.09467 \\
\hline & 3 & Brown & 0.00970 & 0.08350 & 0.04770 & 0.12670 & 0.02790 & 0.06430 & 0.64030 & 0.00415 & 0.00871 & 0.00747 & 0.03474 & 0.04791 & 0.03213 & 0.06314 \\
\hline & 4 & Black & 0.01010 & 0.09240 & 0.04980 & 0.14200 & 0.03300 & 0.01950 & 0.65320 & 0.00436 & 0.00926 & 0.00807 & 0.03631 & 0.04868 & 0.03293 & 0.06740 \\
\hline & 6 & White & 0.00930 & 0.07930 & 0.04920 & 0.14560 & 0.03220 & 0.01970 & 0.66470 & 0.00432 & 0.00928 & 0.00774 & 0.03745 & 0.04839 & 0.03391 & 0.06583 \\
\hline \multirow{6}{*}{ AP7 } & 4 & Support & 0.00880 & 0.06760 & 0.05670 & 0.17160 & 0.03520 & 0.03920 & 0.62080 & 0.00567 & 0.00439 & 0.00781 & 0.04185 & 0.06795 & 0.03672 & 0.12443 \\
\hline & 1 & Black & 0.00840 & 0.06800 & 0.05220 & 0.19510 & 0.03400 & 0.07260 & 0.56960 & 0.00514 & 0.00465 & 0.00801 & 0.04254 & 0.06056 & 0.03772 & 0.11718 \\
\hline & 2 & Orange & 0.00950 & 0.07450 & 0.05620 & 0.22310 & 0.03210 & 0.06550 & 0.53910 & 0.00520 & 0.00450 & 0.00830 & 0.04110 & 0.07427 & 0.03637 & 0.12042 \\
\hline & 3 & Red & 0.00830 & 0.06990 & 0.05390 & 0.21880 & 0.03090 & 0.04700 & 0.57120 & 0.00880 & 0.00419 & 0.00791 & 0.04455 & 0.05943 & 0.03718 & 0.11395 \\
\hline & 5 & Red & 0.00760 & 0.06140 & 0.05190 & 0.20290 & 0.03270 & 0.07530 & 0.56810 & 0.00509 & 0.00395 & 0.00851 & 0.04154 & 0.05556 & 0.03852 & 0.18718 \\
\hline & 6 & Orange & 0.00780 & 0.06180 & 0.05170 & 0.19660 & 0.03400 & 0.05860 & 0.58950 & 0.00500 & 0.00420 & 0.00818 & 0.04100 & 0.07187 & 0.03457 & 0.11442 \\
\hline
\end{tabular}

We attribute the detection of significantly higher levels of Fe in relation to $\mathrm{Si}$ to the depth of analysis of the instrument as well the presence of a thin layer of air. For Si, the penetration depth is relatively shallow and results in the detection of this element within the first $27 \mu \mathrm{m}$ of the surface of silicate-rich geological mediums. Conversely, Fe is detected at depths of up to $300 \mu \mathrm{m}$ (Drake, 2015). Whereas Si has a fluorescence efficiency of $4 \%$ (which means that only 4 in $100 \mathrm{Si}$ atoms fluoresce), Fe has a fluorescence efficiency of $35 \%$. The presence of a thin layer of air between the instrument and the plaques might also have resulted in the 
absorption of signals from elements such as Al, Si and Ca. Examples of ED-XRF spectra of the pigmented areas and underlying rock supports are indicated in Fig. 4. Several analysed points exhibit dissimilar spectral profiles when compared to the relevant rock supports, particularly in the case of $\mathrm{Ca}$, Fe and $\mathrm{Mn}$ (Fig. 4b and c). Peaks arising from the rhodium target tube appear in all ED-XRF spectra and are indicated as such (Rh).

a)

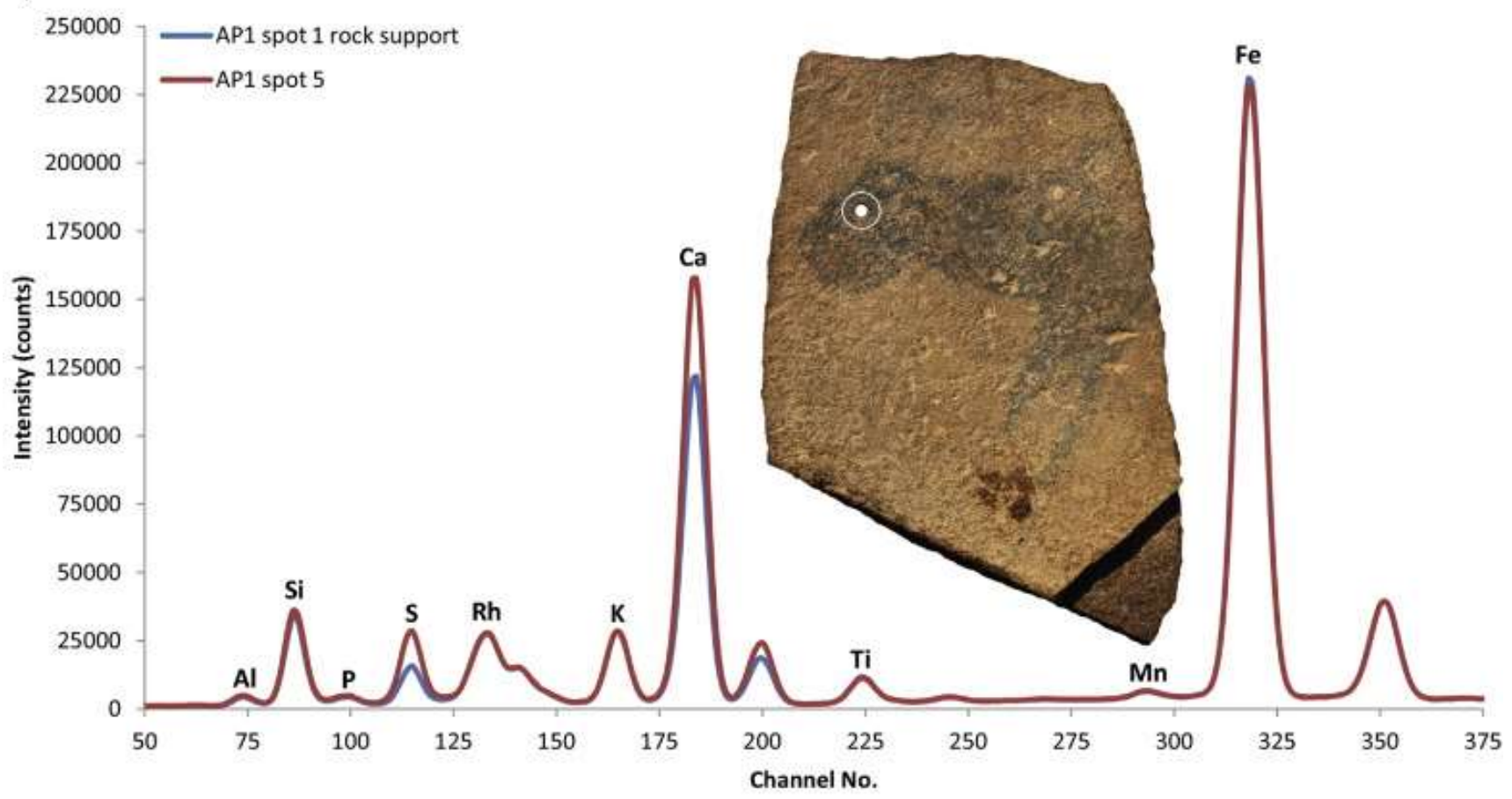

b)

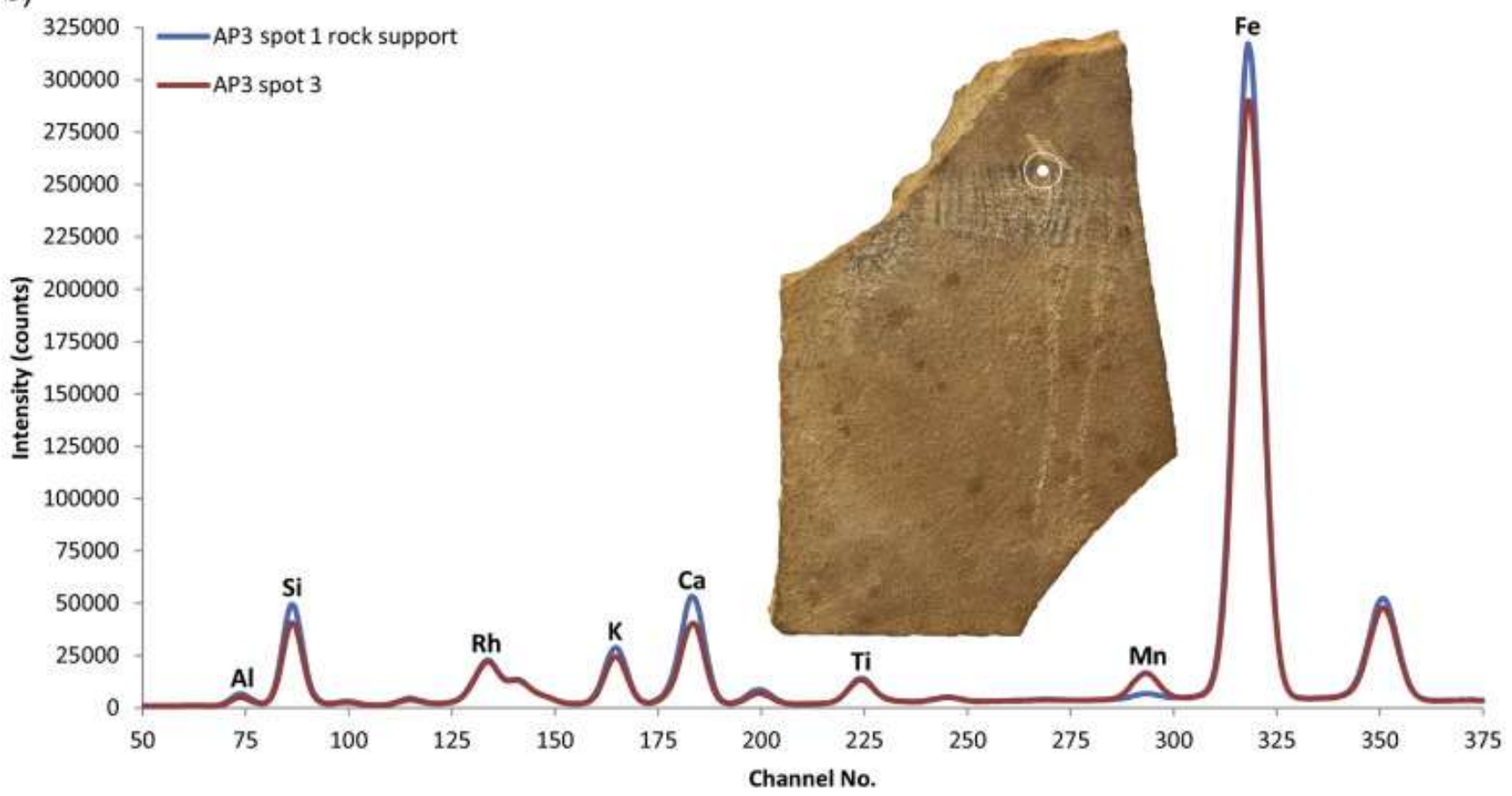


c)

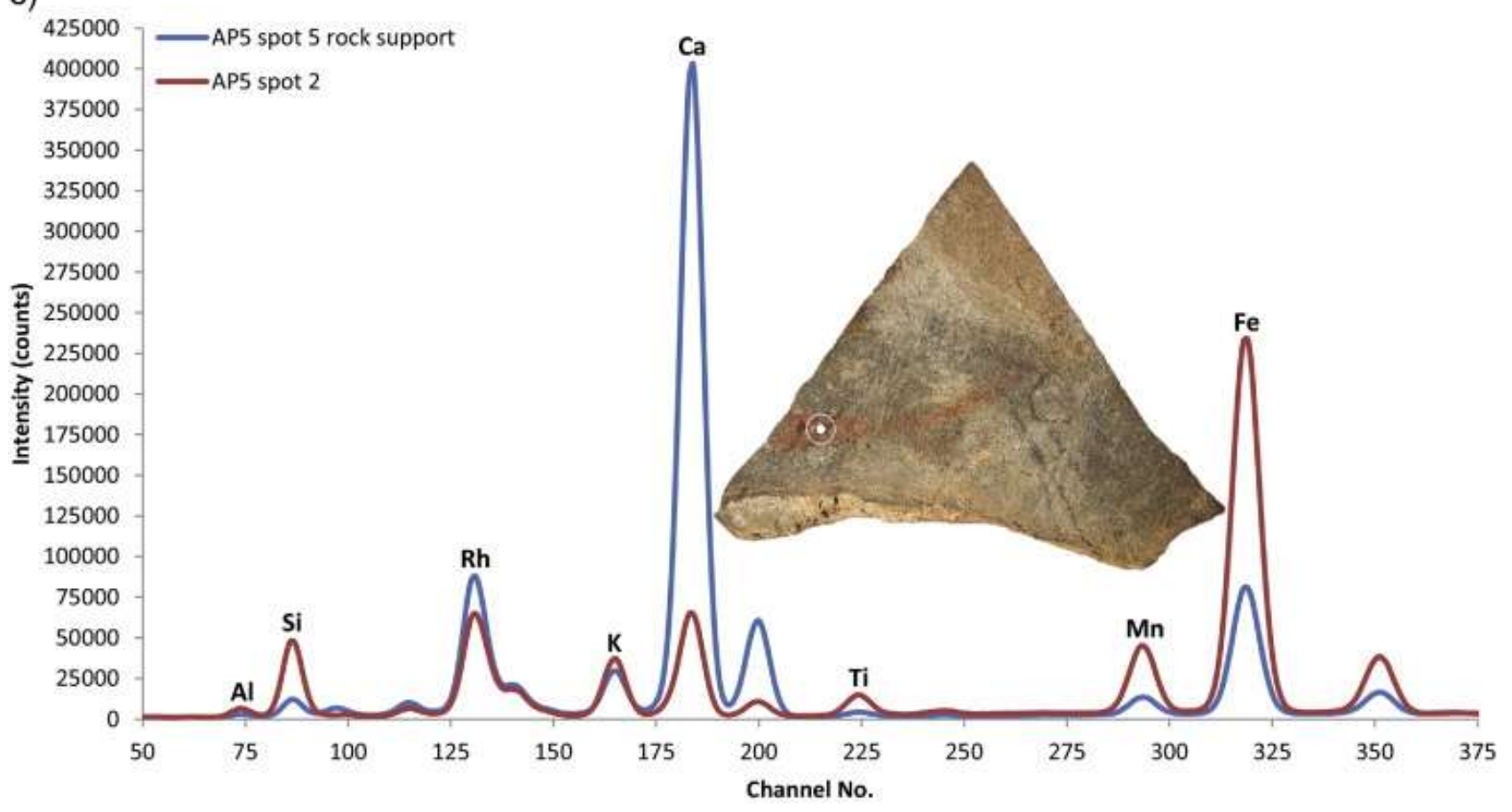

d)

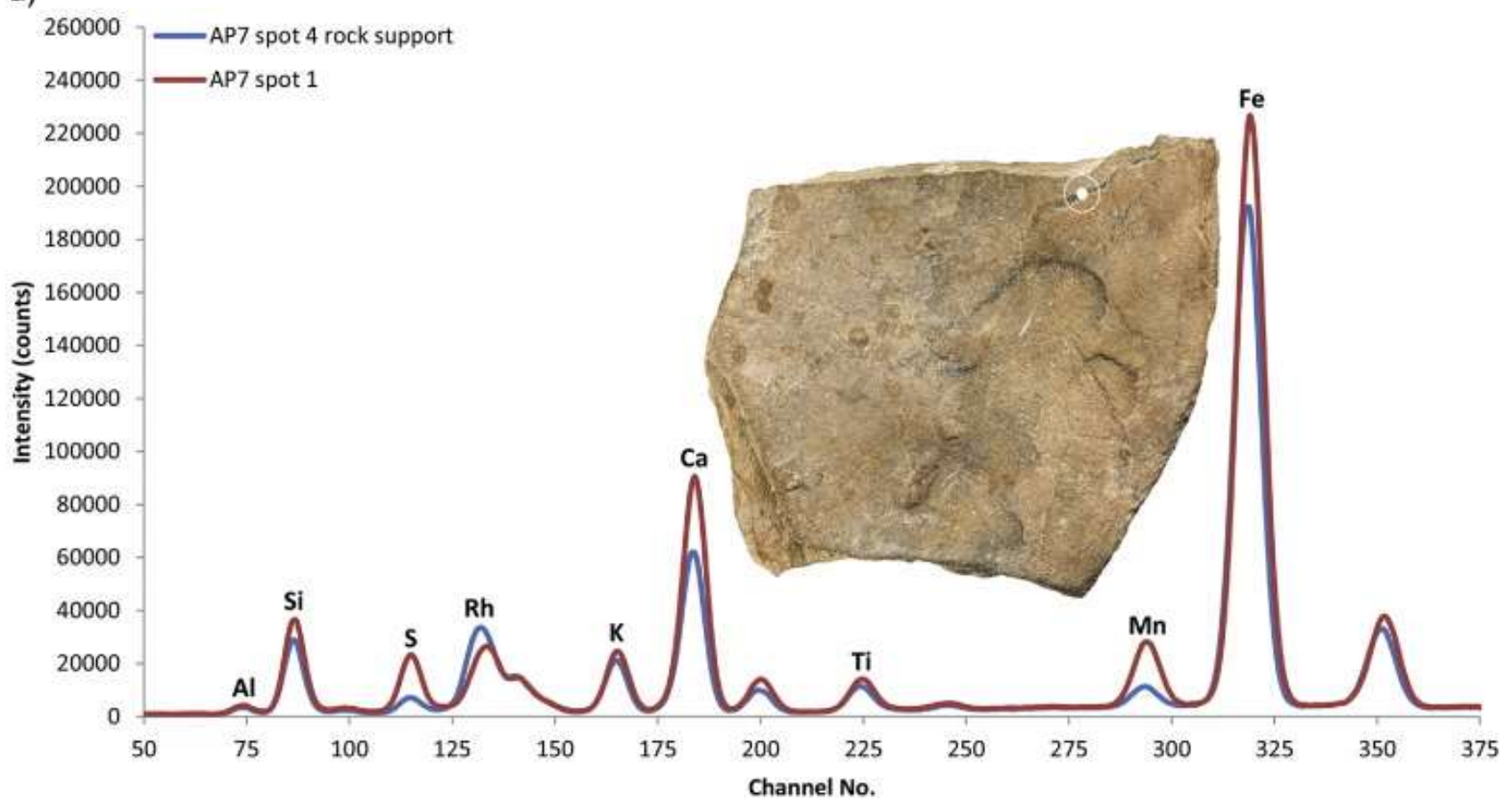

Fig. 4. ED-XRF spectra (15 keV) of traces of black pigment (spot 1) and the rock support surface (spot 5) on AP1 (a), of black pigment (spot 3) and the rock support (spot 1) on AP3 (b), of red pigment (spot 2) and the support (spot 5) on AP5 (c) and of the rock support surface (spot 4) and red pigment (spot 5) on AP7 (d).

To distinguish the elemental composition of pigments from that of the underlying rock surfaces, spectra of pigmented areas were compared with areas that were not covered with pigment. If the spectrum from a black pigmented area was similar to the ED-XRF spectrum, it was deemed probable that the black pigments used were carbon-based (López-Montalvo et al., 2014; Roldán et al., 2012). This is because organic black pigments generally comprise lighter elements that cannot be detected by ED-XRF. In instances where elements such as $\mathrm{Mn}$ and $\mathrm{Fe}$ or $\mathrm{Ba}$, which generally form part of the oxides characteristic of inorganic 
(geologically-derived) black pigments were absent, we conclude that carbon-based pigments were used. Fe is generally the primary component of red pigments, and in samples rich in clay minerals like ochre (red earth) or clayey rocks, Fe is usually mixed with Al, Si and sometimes also $\mathrm{Ca}$. $\mathrm{Ca}$ is an intermittent component which is most often detected in white pigments. Calcite-based materials are the most commonly used white pigments and typically contain Ca but little to no P.

Most of the black pigments do not exhibit marked increases in Mn content, except for AP3 spot 3, in which case we interpret this to be indicative of the use of Mn-based pigments. Higher Ca contents are detected in AP1, AP5 and AP6 in resin- or mastic-like residues and a black and white pigmented areas, respectively. The presence of $\mathrm{Ca}$ in organic deposits could be due to the presence of calcium salts formed during post-depositional processes, or from a recent additive perhaps used during the curation of the plaques. A white deposit underlies the black pigment analysed on AP5. This white pigment, as well as white pigment from other areas on the same plaque, is probably composed of a calcium mineral. The high Ca content observed in the rock support for AP5 is unusual. Although it has been carefully selected to avoid pigment-rich deposits, the light colour of the area analysed suggests that it is in all probability covered by a white deposit. Its composition appears to be similar to that of the white pigment analysed on the support surface of AP5.

No significant differences in Fe content are apparent between either the red pigments or the underlying rock surfaces, nor is this the case for the other detected elements. This is most likely due to the high staining and surface covering capacity, but nevertheless superficial nature, of the red pigmented surfaces. In most instances, the red areas have faded substantially, making it difficult to determine whether these pigments were applied by painting or by drawing. Even the most prominent red layer, present on AP5, is in fact thin enough to expose an underlying black pigment layer. As a result of these ED-XRF related complications, we used FT-IR and Raman spectrometry as complementary analytical techniques for the identification of these pigments.

\subsection{FT-IR spectroscopy}

Since the high fluorescence backgrounds typically encountered during Raman analyses often limits the detection of unknown components (Prinsloo et al., 2013) it was decided to use infrared spectroscopy as a complementary technique. Laboratory and synchrotron-based FT-IR spectroscopic instruments have been used successfully to analyse sampled rock art pigments (Hernanz et al., 2006; Prinsloo et al., 2008; Prinsloo et al., 2013; Prinsloo et al., 2014 ; Goodall et al., 2009). In these studies, the pigment samples were either powdered and mixed with $\mathrm{KBr}$ and pressed into pellets for transmission measurements, or directly analysed using an ATR (attenuated total reflection) cell inside the instrument or attached to a microscope. In all of these instances, the data generated were transmission/absorbance spectra.

Although Raman and XRF portable instruments have been on the market for quite some time, and while numerous studies have reported their successful use in rock art studies (Bonneau et al., 2012; Hernanz et al., 2008; Hernanz et al., 2012; Lufromento et al., 2012 ; Prinsloo et al., 2008), this is not the case for portable reflectance FTIR instruments. 
This is because FTIR reflectance results in a combination of reflection and transmission/absorbance FTIR spectra, which is not always as easy to interpret. However, the increasing availability of portable spectrometers, and the possibility to use reflectance FTIR spectroscopy as non-invasive tool in heritage studies, have resulted in a number of in situ FT-IR reflectance studies on heritage building material, pigments in wall paintings and synthetic alteration of artefacts (Arrizabalaga et al., 2015; Miliani et al., 2012 ; Conti et al., 2013). As far as we can ascertain, this is the first reported use of a portable reflectance FTIR instrument used for the analyses of rock art.

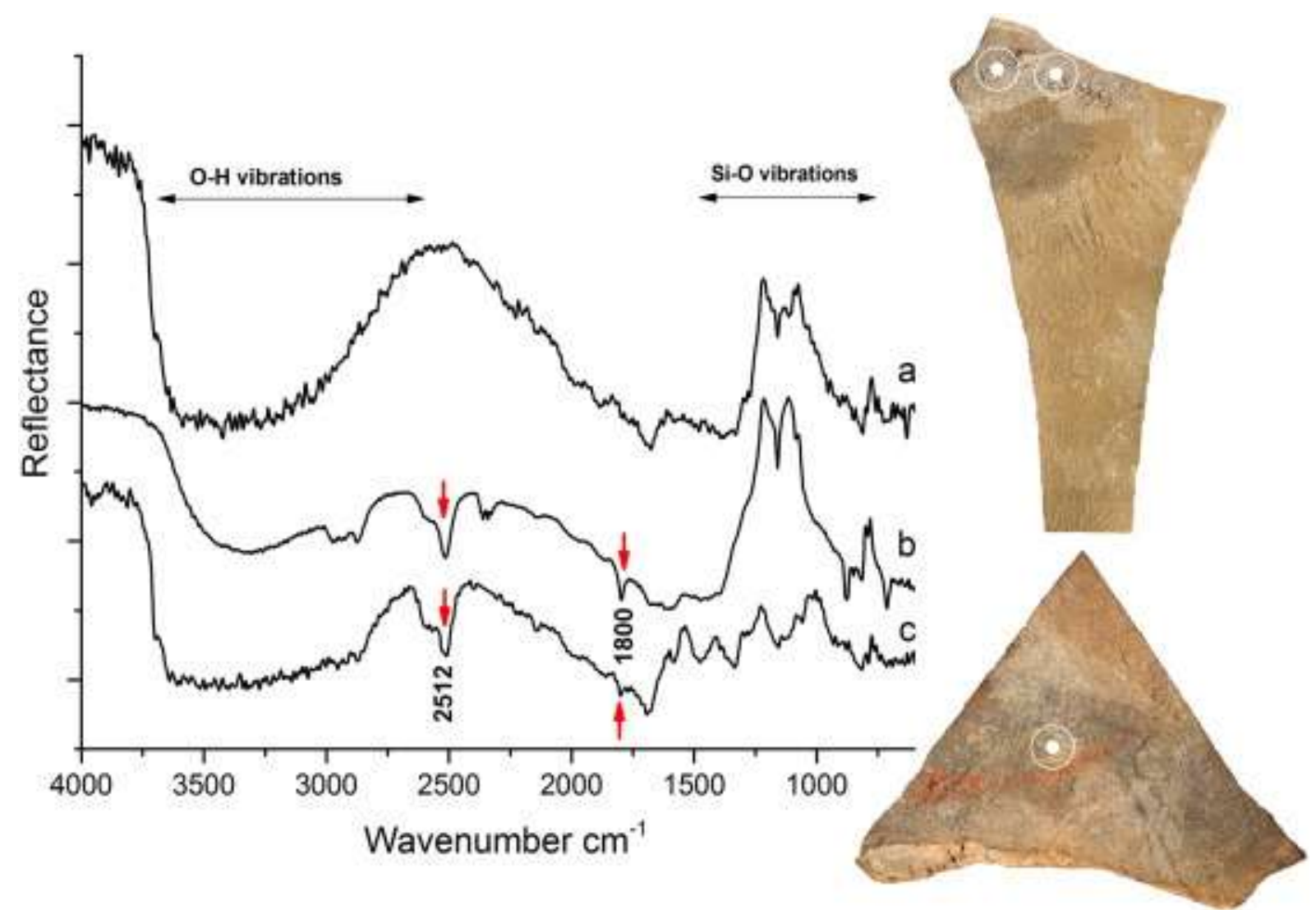

Fig. 5.A reflectance FT-IR spectrum representative of most spectra recorded on the Apollo 11 plaques (a) and a spectrum recorded for ostrich eggshell used as crayon to scribble on a quartzite surface (b). Comparable spectra were recorded for the residual crust on AP6 (spots 1 and 2 indicated at top right) and for the white pigment on AP5 (spot 9 at bottom right) (c).

In Fig. 5, the top spectrum (Fig. 5a) is representative of nearly all the spectra recorded on the samples, with the strong bands in the area of Si__ o vibrations $\left(820-1290 \mathrm{~cm}^{-1}\right)$ originating from the reststrahlen (residual rays) bands of the rock substrate consisting mostly of $\alpha$-quartz. Although occurring at similar positions as true absorption/transmission bands, the origin of the reststrahlen bands are slightly different. Light is selectively reflected from the surface of a solid when the frequency of the light is nearly equal to the vibration frequency of the electrically charged atoms or ions, constituting the crystalline solid. The resulting reflection is known as reststrahlen (Prinsloo et al., 2014). It should be noted that, when recording spectra in reflectance mode, absorptions appear as transmission spectra with the peak maxima in the opposite direction as the reflectance peaks. In some instances, we detected additional spectral bands (opposite direction of the reflectance bands), such as 
in spectrum c (Fig. 5c) recorded for white pigment on AP6 (spots 1 and 2) and AP5 (spot 9). Prehistoric white pigments generally comprise white clay, hyena dung, raptor faeces or the combustion products of ostrich eggshell or bone (Prinsloo et al., 2013). Since calcite $\left(\mathrm{CaCO}_{3}\right)$ has been detected in South African rock art pigments (Tournié et al., 2010), and given that

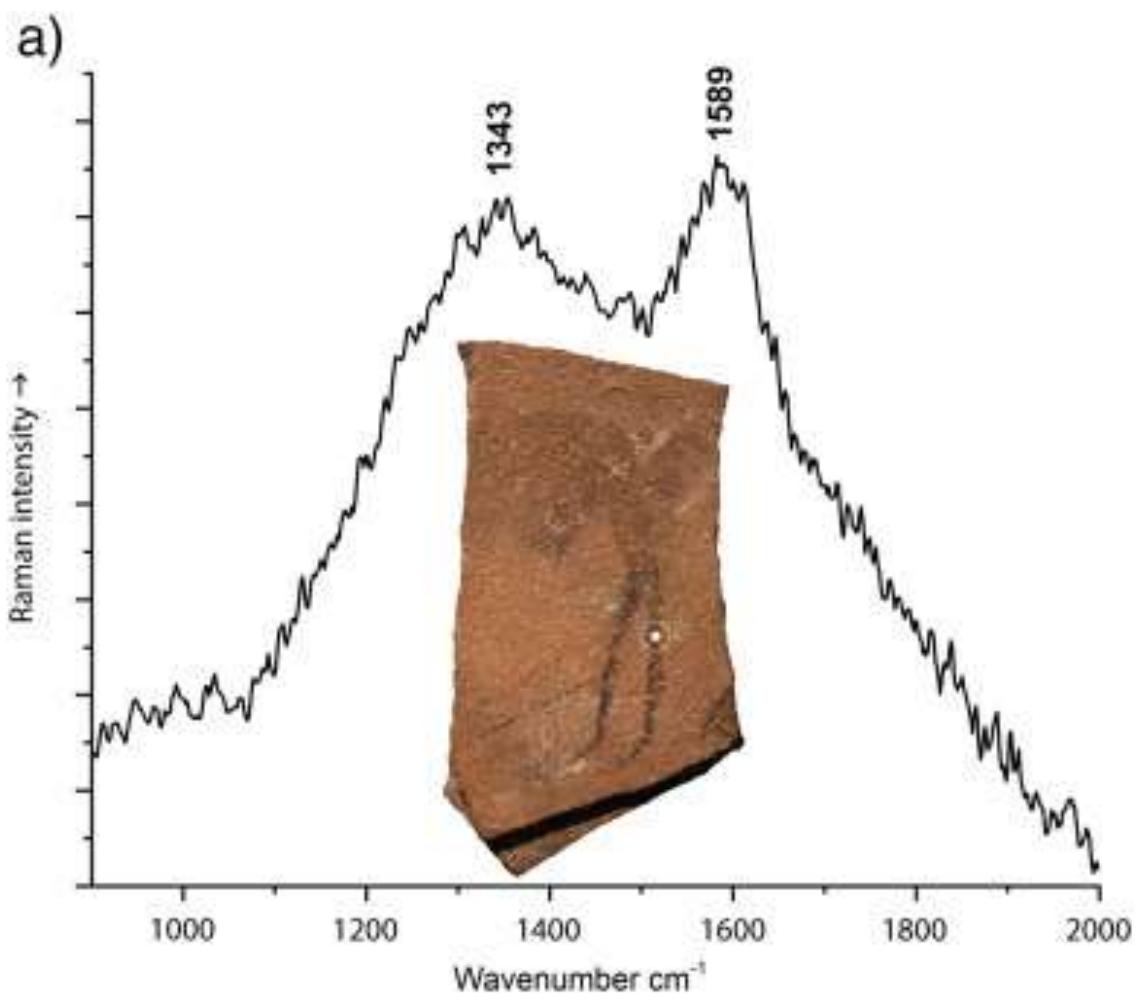

b)

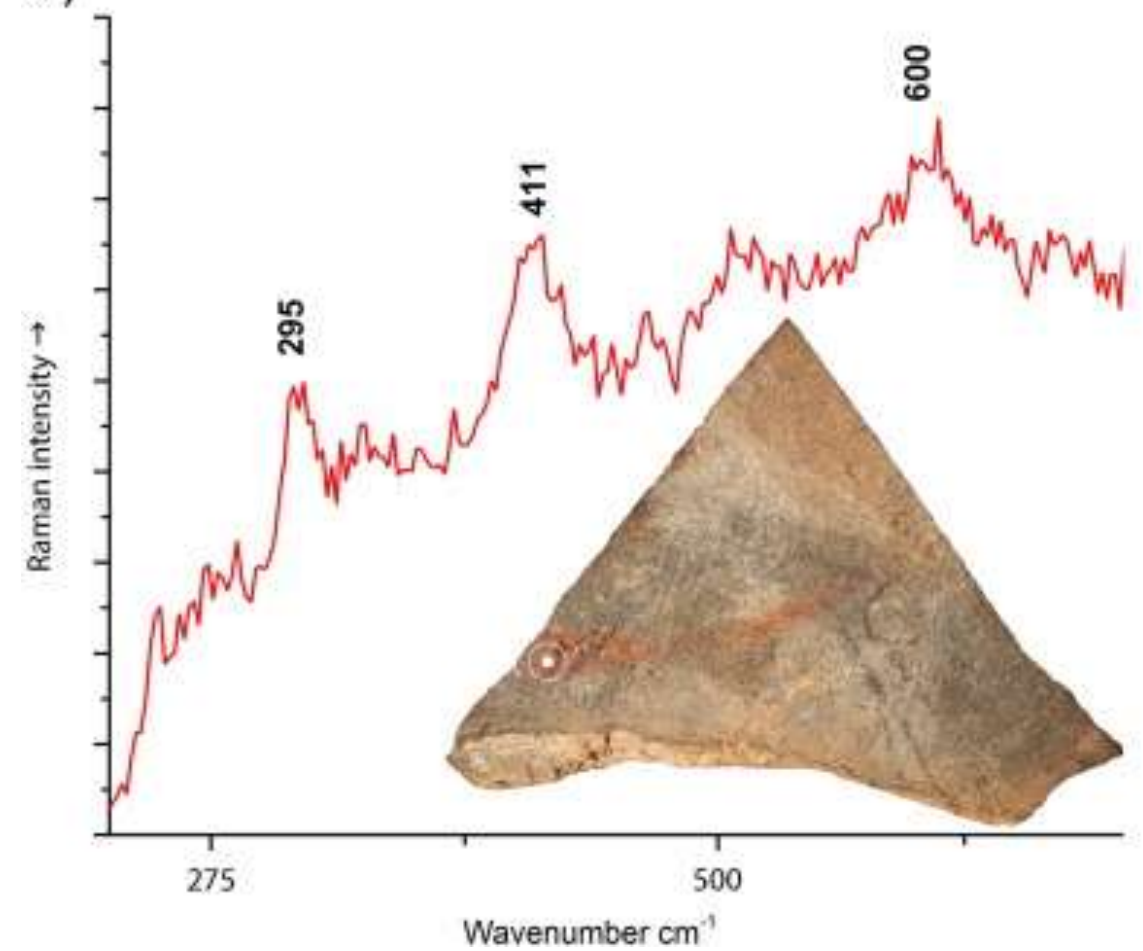

Fig. 6. Raman spectra provides a clear carbon signature for the black pigment on the 'leg' of AP2 (spot 4). Peaks are assigned as bands D and $G$ typical of carbon structures (a). The presence of hematite on AP5 (spot 2) is indicated by the peaks at $295 \mathrm{~cm}^{-1}, 411 \mathrm{~cm}^{-1}$ and $611 \mathrm{~cm}^{-1}(\mathrm{~b})$. 
an abundance of ostrich eggshell fragments were excavated at the site, we produced a reference sample in reflectance mode of calcite by scratching ostrich eggshell ( $98 \%$ calcite) fragments onto a piece of quartzite. A spectrum of this sample (Fig. 5b) was recorded with a Hyperion microscope attached to a Vertex 70v (Bruker Optics) spectrometer and comprise strong reflectance bands of the quartz substrate and the same two bands at 1800 and $2512 \mathrm{~cm}^{-1}$ in spectrum c.

Calcite is identified in absorbance/transmission infrared spectra by a strong band at $1410 \mathrm{~cm}^{-1}$ and a characteristic sharp band at $872 \mathrm{~cm}^{-1}$. In reflection spectra, this region is dominated by the reststrahlen band of the rock substrate and the calcite bands are distorted. The combination bands (sum or difference of fundamental bands) are enhanced in reflection spectra. It has been shown that the $v 1+v 4$ and $v 1+v 3$ bands can be used to identify carbonates and for calcite the bands occur at $1800 \mathrm{~cm}^{-1}$ and $2512 \mathrm{~cm}^{-1}$, respectively ( Arrizabalaga et al., 2015 ; Miliani et al., 2012). It is clear in Fig. 6 that both these diagnostic bands are present in the spectrum recorded on the rock art sample. Although calcite was positively identified, and in all probability does derive from using ostrich eggshell as a crayon, it is not possible to distinguish between ostrich eggshell and calcite derived from other sources. Ostrich eggshell generally does not produce a great pigment, but if heated until combustion occurs, the resultant product $(\mathrm{CaO}$, generally known as lime and used as building material since pre-historic times) produces a superb pigment (Prinsloo et al., 2013) which can be mixed with a binder to form a paint. Over time, $\mathrm{CaO}$ combines with atmospheric $\mathrm{CO}_{2}$ to produce $\mathrm{CaCO}_{3}$ which presents a similar spectrum as unprocessed ostrich eggshell.

As expected, we did not obtain spectra from the black, red and yellow pigments, primarily because black pigments tend to absorb infrared radiation and because the vibrational bands associated with red and yellow iron oxides fall outside the region measured with a portable FT-IR instrument.

\subsection{Raman spectroscopy}

Raman spectroscopy has been used effectively to analyse pigments both in the laboratory (Bonneau et al., 2012; Hernanz et al., 2008; Hernanz et al., 2012; Lufromento et al., 2012 ; Prinsloo et al., 2008) and on-site (Lahlil et al., 2012; Olivares et al., 2013 ; Tournié et al., 2010) and the use of portable instruments are well documented. In spite of using the red $785 \mathrm{~nm}$ laser line as excitation source, selected to be outside the wavenumber region of fluorescence originating from most organic materials (Prinsloo et al., 2013), most spectra exhibited strong fluorescence. The spectra quality was also poor, which may be due to the fact that it was difficult to focus the spectra and to select optimally pigmented spots (the microscope attached to the instrument could not be used due to sample thickness). Another reason might be the accumulation of dust and other atmospheric pollution on samples in storage (Tournié et al., 2010). It was nevertheless possible to identify some pigments, including the presence of carbon-derived black pigments, most likely charcoal, on several areas on AP2 (Fig. 6a) and also hematite (Fe-rich red pigment) on AP5 (Fig. 6b).

Table 4 provides a summary of the colourimetric ( $\left.L^{*} a * b *\right)$, elemental (ED-XRF) and organic and inorganic (FT-IR and Raman) composition of the pigments present on the plaques. 
Based on our observations under low magnification, we also provide information concerning the range of techniques most probably used to apply pigments to the plaques (see Online Resource 2).

Table 4. ED-XRF, FT-IR and Raman results and colourimetric coordinates (CIE- $\mathrm{L}^{*} \mathrm{a}{ }^{*} \mathrm{~b}^{*}$ ) for the pigments present on AP1 to AP7.

\begin{tabular}{|c|c|c|c|c|c|c|c|}
\hline Plaque & Spot & Description & ED-XRF & FT-IR & Raman & $\Delta E^{*}{ }_{2000}$ & Technique \\
\hline \multirow[t]{6}{*}{ AP1 } & 5 & Rock support & $\begin{array}{l}\text { Al Si K Ca } \\
\text { Ti Fe Mn }\end{array}$ & & $\mathrm{TiO} ?$ & & \multirow{6}{*}{$\begin{array}{l}\text { Painted, drawn, rubbed } \\
\text { and pecked }\end{array}$} \\
\hline & 1 & Black pigment & $?$ & & Carbon & 34.09 & \\
\hline & 2 & Red deposit/pigment & $?$ & & & 17.69 & \\
\hline & 3 & White deposit/pigment & $?$ & & $\mathrm{CaCO} 3$ & 17.34 & \\
\hline & 4 & Black pigment & $?$ & & Carbon & 32.77 & \\
\hline & 6 & Brown residue/deposit & $\mathrm{Ca}$ & & & 22.49 & \\
\hline \multirow[t]{6}{*}{ AP2 } & 6 & Rock support & $\begin{array}{l}\text { Al Si K Ca } \\
\text { Ti Fe Mn }\end{array}$ & & & & \multirow{6}{*}{$\begin{array}{l}\text { Drawn and painted? } \\
\text { Redrawn }\end{array}$} \\
\hline & 1 & Black pigment & $?$ & & Carbon & 34.13 & \\
\hline & 2 & White deposit/pigment & $?$ & & & 14.94 & \\
\hline & 3 & Red deposit/pigment & $?$ & & & 20.77 & \\
\hline & 4 & Black pigment & $?$ & & Carbon & 43.61 & \\
\hline & 5 & Black pigment & $\mathrm{Ca}$ & & Carbon & 45.74 & \\
\hline \multirow[t]{5}{*}{ AP3 } & 1 & Rock support & $\begin{array}{l}\text { Al Si K Ca } \\
\text { Ti Fe Mn }\end{array}$ & & Carbon & & \multirow{5}{*}{$\begin{array}{l}\text { Painted and drawn. } \\
\text { Engraved? }\end{array}$} \\
\hline & 2 & $\begin{array}{l}\text { White pigment (some } \\
\text { black pigment) }\end{array}$ & $\mathrm{Ca}$ & & & 11.54 & \\
\hline & 3 & $\begin{array}{l}\text { Black pigment (some } \\
\text { white pigment) }\end{array}$ & $\mathrm{Mn}$ & & & 31.33 & \\
\hline & 4 & White pigment & $?$ & & & 16.45 & \\
\hline & 5 & White pigment & $?$ & & & 13.11 & \\
\hline \multirow[t]{5}{*}{ AP4 } & 2 & Rock support & $\begin{array}{l}\text { Si Al K Ca } \\
\text { Ti Fe Mn }\end{array}$ & & & & \multirow{5}{*}{$\begin{array}{l}\text { Painted and drawn. } \\
\text { Redrawn? }\end{array}$} \\
\hline & 1 & Black pigment & $?$ & & Carbon & 83.62 & \\
\hline & 3 & Red deposit/pigment & Si K & & & 18.83 & \\
\hline & 4 & Black pigment & Si Fe & & Carbon & 9.62 & \\
\hline & 5 & White deposit/pigment & $\mathrm{Cl}$ & & & 85.31 & \\
\hline \multirow[t]{7}{*}{ AP5 } & 5 & $\begin{array}{l}\text { Rock support/white } \\
\text { deposit }\end{array}$ & $\begin{array}{l}\text { Al Si K Ca } \\
\text { Ti Fe Mn }\end{array}$ & & & & \multirow{7}{*}{$\begin{array}{l}\text { Painted, drawn, rubbed } \\
\text { and redrawn }\end{array}$} \\
\hline & 1 & Red and black pigments & $\begin{array}{l}\text { Al Si K Ti } \\
\text { Fe Mn }\end{array}$ & & Hematite & 33.07 & \\
\hline & 2 & Red pigment & $\begin{array}{l}\text { Al Si K Ti } \\
\text { Fe Mn }\end{array}$ & & Hematite & 24.46 & \\
\hline & 3 & $\begin{array}{l}\text { Black and white pigments } \\
\text { (grey) }\end{array}$ & $\begin{array}{l}\text { Al Si K Ti } \\
\text { Fe Mn }\end{array}$ & & & 21.81 & \\
\hline & 4 & $\begin{array}{l}\text { White pigment (some } \\
\text { black pigment) }\end{array}$ & $\begin{array}{l}\text { Al Si K Ti } \\
\text { Fe Mn }\end{array}$ & & & 23.37 & \\
\hline & 6 & $\begin{array}{l}\text { Black pigment (some } \\
\text { white pigment) }\end{array}$ & $\begin{array}{l}\text { Al Si K Ca } \\
\text { Ti Fe Mn }\end{array}$ & & & 48.22 & \\
\hline & 7 & Black pigment & Al Si K Ti & & & 38.48 & \\
\hline
\end{tabular}




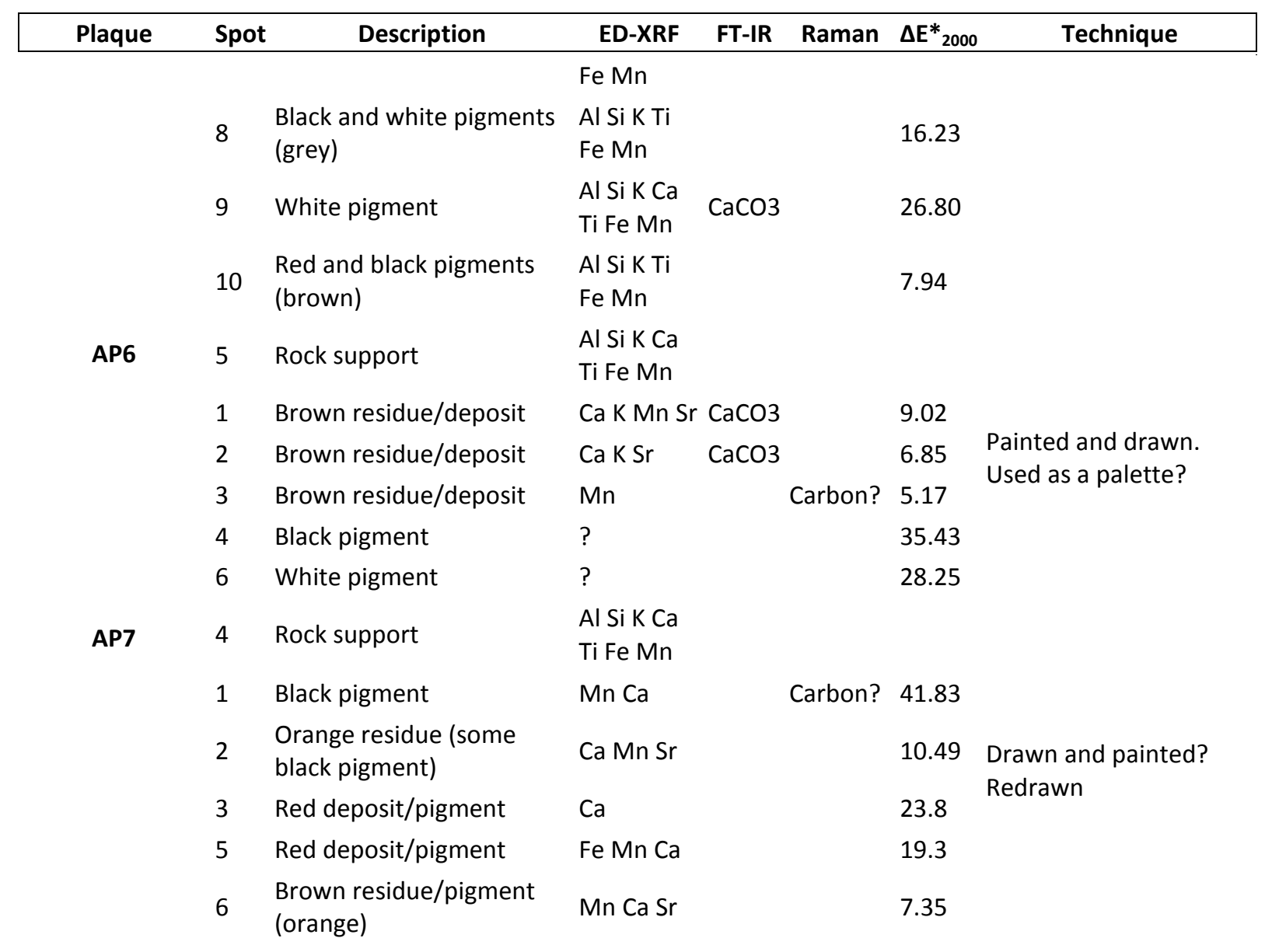

\section{Discussion}

Our analyses indicate that a combination of mineral- and organically-derived pigments and techniques was used to create the figurative imagery on the Apollo 11 plaques (Table 4). The absence of $P$ in the ED-XRF spectra excludes the use of black pigments obtained from bone and suggests the use of wood-derived charcoal black pigments. The black pigments on AP3, and to a lesser extent on AP7, exhibit elevated concentrations of Mn, suggesting that black or brown Mn-rich mineral pigment was used to create at least some parts of the images. The lack of notable changes in the elemental composition of black pigments and rock supports for AP1, AP2, AP4 and AP6 indicate that these pigments are in all probability carbon-based. Charcoal-derived pigments have been identified on southern African San rock art (Bonneau et al., 2012 ; Prinsloo et al., 2008) and also in French Palaeolithic caves (Chalmin et al., 2003). Raman spectra provide a strong carbon signature for the pigment on AP2 (spot 4) (Fig. 6a). The tentative identification of carbon traces in the pigments of AP7 (spot 1) (1300 $\mathrm{cm}^{-1}$ to $\left.1600 \mathrm{~cm}^{-1}\right)$ suggests that the artists may have used a combination of black pigments derived from both charcoal and manganese to create the imagery (Fig. 4b). CIE (L*a*b*) colourimetric values do not facilitate the discrimination between carbon-based and $\mathrm{Mn}$-based black pigments identified by ED-XRF and Raman. The presence of hematite derived from red mineral pigment on AP5 (spot 2) is not indicated particularly well by the ED-XRF results, but is confirmed by the Raman peaks recorded (Fig. 6b). 
The differential elemental composition of pigments and supports for AP 6 (spots 1 and 2) confirms the presence of $\mathrm{Ca}$. The probable use of ostrich eggshell as a white pigment is indicated by the spectral bands recorded on AP6 (spots 1 and 2) and AP5 (spot 9) (Fig. 5). Colour measurement values are also most pronounced for the white pigments, specifically those on AP5 (spot 9). White pigment on AP1 (spot 3) was identified to comprise $\mathrm{CaCO}_{3}$. AP3, AP4, AP6 and AP7 contain visible traces of a flaky, white translucent substance which may be the remains of a white pigment or a preparatory base. San artists possibly prepared rock surfaces for painting by washing with acidic liquids such as plant or fruit juice (Bonneau et al., 2012).

The images were created by way of a combination of different techniques (Table 4 and Online Resource 2). In Chauvet Cave (Ardèche, France), a combination of charcoal drawing, including modification by using fingers to blur or smudge lines, and fine engravings, was used to create figurative images at $30 \mathrm{ka}$ (Fritz and Tosello, 2007). At $17 \mathrm{ka}$, the Great Bull in Lascaux Cave (Dordogne, France), was drawn with manganese oxides, charcoal and red ochre (Chalmin et al., 2007), and at Rouffignac Cave (13.5 ka), mammoths were engraved and drawn with manganese crayons (Lahlil et al., 2012). The use of both mineral- and carbon-based 'crayons' is therefore not unusual, but this study presents the first evidence for its combined use in the southern African MSA. Based on our visual macroscopic examination of the plaques, and on previous experimental work (Rifkin, 2012), the granular appearance of black pigments on AP2 and on AP5 suggests that these lines were in all probability applied in dry form, likely with a charcoal crayon. In contrast, some of the plaques bear residual traces of former liquid and possibly paint-like mixtures. The occurrence of a thick white residue rich in red and black particles on AP6 suggests that it may have been used as a palette on which to mix pigmentatious ingredients. AP7 exhibits traces of black, white, orange and red pigments and several semi-circular remnants of what may represent dried-out traces of liquid paint drops (Rifkin et al., 2015). The homogenous distribution of black pigment on AP1 and white pigment on AP3 and AP5 suggests that these were applied to the plaques in liquid form. The white translucent substance on AP3, AP4 and AP6, thought to represent a white pigment or preparatory base, was also applied in liquid form. AP3 and AP6 furthermore provide evidence that black pigments were applied, by drawing, over white painted background surfaces. The temporal succession of pigments present on the plaques also point towards their social circulation and curation. Instances of superpositioning on AP3 and AP6, and on AP5 in particular, demonstrate that different types of pigments were repeatedly applied to this plaque, perhaps to restore older faded images and to create new depictions.

\section{Conclusion}

The greatest limitation of this study was the inability to subject the Apollo 11 plaques to laboratory-based analytical procedures. It was therefore essential to consider the application of suitable portable analytical instruments that could be used to analyse the artefacts on the premises of the National Museum of Namibia in Windhoek. Despite the fact that these portable instruments are not as precise as their laboratory-based versions, the ED-XRF, FT-IR and Raman equipment used in this study did facilitate the identification of at least four types of pigments (including red ochre-, black manganese- and charcoal- and white ostrich eggshell-derived pigments) used in the production of the imagery on the 
plaques. Most studies aimed at ascertaining the composition of pigments used in parietal southern African San hunter-gatherer art confirm that red pigments most frequently derive from red ochre or hematite, that yellow pigments derive from yellow ochre or goethite, white generally comprise calcite, gypsum or, less frequently, white clay and that black pigments most often consist of amorphous carbon or manganese oxides (Rudner, 1983; Prinsloo et al., 2008 ; Prinsloo et al., 2013; Bonneau et al., 2012).

Taking into account the increasing affordability of portable analytical instruments in relation to costly and stationary bench-top laboratory equipment, portable ED-XRF, Raman and FT-IR devices do provide viable alternatives to destructive sampling techniques and the problems associated with immobile analytical instruments. The results reported here therefore demonstrate the importance and advantages, and also the shortcomings, of using portable analytical techniques in studying the composition prehistoric pigments. It is known that MSA humans possessed the capacity to produce composite red ochre-based pigment mixtures at $100 \mathrm{ka}$ (Henshilwood et al., 2011) and also at $50 \mathrm{ka}$ (Villa et al., 2015), but the Apollo 11 art mobilier provides the first indication, in Africa, of the uses to which such paint-like compounds may have been put. In addition, and besides the incidence of red ochre particles in perforated shell beads from African and Near Eastern MSA and Levantine Mousterian sites dated from 92 ka to 60 ka (Bouzouggar et al., 2007; d'Errico et al., 2005 ; Vanhaeren et al., 2006), this study provides direct evidence for the use of pigment-rich compounds to create figurative depictions.

\section{Acknowledgements}

We express thanks to W. Erich Wendt for his time and to Antje Otto for arranging our meeting with him. Permission to conduct this research was granted by the National Heritage Council of Namibia and the National Museum of Namibia (permit number 25/2013). Esther Moombolah-Goagoses and Emma Imalwa (National Museum of Namibia) are thanked for their support. Pieter Norval and Shawn Britz (Separation Scientific Johannesburg, South Africa) and Lee Drake (Bruker Elemental, Madison, WI, United States of America) are thanked for their analytical support. RFR acknowledges financial support provided by the Palaeontological Scientific Trust (PAST). Financial support was provided to CSH by a South African National Research Foundation SARChI Chair at the University of the Witwatersrand and by the University of Bergen, Norway.

\section{References}

Arrizabalaga, I., Gómez-Laserna, O., Carrero, J.A., Bustamante, J., Rodríguez, A., Arana, G., Madariaga, J.M., 2015. Diffuse reflectance FTIR database for the interpretation of the spectra obtained with a handheld device on built heritage materials. Anal. Methods 7, 1061-1070.

Bonneau, A., Pearce, D.G., Pollard, A.M., 2012. A multi-technique characterization and provenance study of the pigments used in San rock art, South Africa. J. Archaeol. Sci. 39, 287-294.

Bouzouggar, A., Barton, N., Vanhaeren, M., d'Errico, F., Collcutt, S., Higham, T., Hodge, E., Parfitt, S., Rhodes, E., Schwenninger, J.L., Stringer, C., Turner, E., Ward, S., Moutmir, A., Stamboul, A., 2007. 82 000-year-old shell beads from North Africa and implications for the origins of modern human behaviour. Proc. Natl. Acad. Sci. U. S. A. 104, 9964-9969. 
Chalmin, E., Menu, M., Vignaud, C., 2003. Analysis of rock art painting and technology of Palaeolithic painters. Meas. Sci. Technol. 14 (9), 1590-1597.

Chalmin, E., Vignaud, C., Salomon, H., Farges, F., Susini, J., Menu, M., 2007. Minerals discovered in Palaeolithic black pigments by transmission electron microscopy and micro-X-ray absorption near-edge structure. Appl. Phys. A Mater. Sci. Process. 83 (2), 213-218.

Conti, C., Striova, J., Aliatis, I., Colombo, C., Greco, M., Possenti, E., Realini, M., Brambilla, L., Zerbi, G., 2013. Portable Raman versus portable mid-FTIR reflectance instruments to monitor synthetic treatments used for the conservation of monument surfaces. Anal. Bioanal. Chem. 405, 1733-1741.

d'Errico, F., Henshilwood, C.S., Vanhaeren, M., van Niekerk, K., 2005. Nassarius kraussianus shell beads from Blombos Cave: evidence for symbolic behaviour in the Middle Stone Age. J. Hum. Evol. 48, 3-24.

d'Errico, F., Garcia Moreno, R., Rifkin, R.F., 2012a. Technological, elemental and colorimetric analysis of an engraved ochre fragment from the Middle Stone Age levels of Klasies River Cave 1, South Africa. J. Archaeol. Sci. 39 (4), 942-952.

d'Errico, F., Backwell, L., Villa, O., Degano, I., Lucejko, J.J., Bamford, M.K., Higham, T.F.G., Colombini, M., Beaumont, P.B., 2012b. Early evidence of San material culture represented by organic artifacts from Border Cave, South Africa. Proc. Natl. Acad. Sci. U. S. A. 109 (33), 13214-13219.

Drake, B.L., 2015. XRF user guide: depth of analyses Accessed on 15 October 2015. Available only at http://www.xrf.guru/styled-12/page40/index.html.

Frausto-Reyes, C., Ortiz-Morales, M., Bujdud-Pérez, J.M., Magana-Cota, G.E., Mejía-Falcón, R., 2009. Raman spectroscopy for the identification of pigments and color measurement in Dugès watercolors. Spectrochim. Acta Mol. Biomol. 74, 1275-1279.

Fritz, C., Tosello, G., 2007. The hidden meaning of forms: methods of recording Paleolithic parietal art. J. Archaeol. Method Theory 14 (1), 48-80.

Goodall, R.A., David, B., Kershaw, P., Fredericks, P.M., 2009. Prehistoric hand stencils at Fern Cave, North Queensland (Australia): environmental and chronological implications of Raman spectroscopy and FT-IR imaging results. J. Archaeol. Sci. 36, 2617-2624.

Harman, J., 2008. Using Decorrelation Stretch to enhance rock art images. Paper presented at the American Rock Art Research Association annual meeting on 28 May 2005 (consulted January 2015) (http://www.dstretch.com/AlgorithmDescription.html).

Henshilwood, C.S., d'Errico, F., 2011. Middle Stone Age Engravings and Their Significance for the Debate on the Emergence of Symbolic Material Cultures. In: Henshilwood, C.S., d'Errico, F. (Eds.), Homo Symbolicus: The Dawn of Language, Imagination and Spirituality. John Benjamins, Amsterdam, pp. 75-96.

Henshilwood, C.S., d'Errico, F., Watts, I., 2009. Engraved ochres from Middle Stone Age levels at Blombos Cave, South Africa. J. Hum. Evol. 57, 27-47.

Henshilwood, C.S., d'Errico, F., van Niekerk, K.L., Coquinot, Y., Jacobs, Z., Lauritzen, S., Menu, M., GarcíaMoreno, R., 2011. A 100,000-year-old ochre-processing workshop at Blombos Cave, South Africa. Science 334 (6053), 219-222. 
Henshilwood, C.S., van Niekerk, K.L., Wurz, S., Delagnes, A., Armitage, S.L., Rifkin, R.F., Douze, K., Keene, P., Haaland, M.M., Reynard, J., Discamps, E., Mienies, S.S., 2014. Klipdrift shelter, southern Cape, South Africa: preliminary report on the Howiesons Poort layers. J. Archaeol. Sci. 45, 284-303.

Hernanz, A., Mas, M., Gavilán, B., Hernández, B., 2006. Raman microscopy and IR spectroscopy of prehistoric paintings from Los Murciélagos cave (Zuheros, Córdoba, Spain). J. Raman Spectrosc. 37, 492-497.

Hernanz, A., Gavira-Vallejo, J.M., Ruiz-Lopez, J.F., Edwards, H.G.M., 2008. A comprehensive micro-Raman spectroscopic study of prehistoric rock paintings from the Sierra de las Cuerdas, Cuenca, Spain. J. Raman Spectrosc. 39, 972-984.

Hernanz, A., Gavira-Vallejo, J.M., Ruiz-López, J.F., Martin, S., Maroto-Valiente, A., De Balbín-Behrmann, R., Menéndez, M., 2012. Spectroscopy of Palaeolithic rock paintings from the Tito Bustillo and El Buxu Caves, Asturias, Spain. J. Raman Spectrosc. 43, 1644-1650.

Jacobs, Z., Roberts, R.G., Galbraith, R.F., Deacon, H.J., Grün, R., Mackay, A., Mitchell, P., Vogelsang, R., Wadley, L., 2008. Ages for the Middle Stone Age of southern Africa: implications for human behaviour and dispersal. Science 322, 733-735.

Lahlil, S., Lebon, M., Beck, L., Rousselière, H., Vignaud, C., Reiche, I., Menu, M., Paillet, P., Plassard, F., 2012. The first in situ micro-Raman spectroscopic analysis of prehistoric cave art of Rouffignac St-Cernin, France. J. Raman Spectrosc. 43 (11), 1637-1643.

León, K., Mery, D., Pedreschi, F., León, J., 2006. Color measurement in L*a*b* units from RGB digital images. Food Res. Int. 39, 1084-1091.

Lewis-Williams, J.D., 1981. Believing and Seeing: Symbolic Meanings in Southern San Rock Paintings. Academic Press, London.

Lewis-Williams, J.D., 2006. Debating rock art: myth and ritual, theories and facts. S. Afr. Archaeol. Bull. 61 (183), 105-114.

Lombard, M., 2012. Thinking through the Middle Stone Age of sub-Saharan Africa. Quat. Int. 270, $140-155$.

López-Montalvo, E., Villaverde, V., Roldán, C., Murcia, S., Badal, E., 2014. An approximation to the study of black pigments in Cova Remigia (Castellón, Spain). Technical and cultural assessments of the use of carbonbased black pigments in Spanish Levantine rock art. J. Archaeol. Sci. 52, 535-545.

Lufromento, C., Ricci, M., Bachechi, L., De Feo, D., Castellucci, E.M., 2012. The first spectroscopic analysis of Ethiopian prehistoric rock painting. J. Raman Spectrosc. 43, 809-816.

Mackay, A., Welz, A., 2008. Engraved ochre from a Middle Stone Age context at Klein Kliphuis in the Western Cape of South Africa. J. Archaeol. Sci. 35, 1521-1532.

Marean, C.W., Bar-Matthews, M., Bernatchez, J., Fisher, E., Goldberg, P., Herries, A.I.R., Jacobs, Z., Jerardino, A., Karkanas, P., Minichillo, T., Nilssen, P.J., Thompson, E., Watts, I., Williams, H.M., 2007. Early human use of marine resources and pigment in South Africa during the Middle Pleistocene. Nature 449, 905-908.

Miliani, C., Rosi, F., Daveri, A., Brunetti, B.G., 2012. Reflection infrared spectroscopy for the non-invasive in situ study of artists' pigments. Appl. Phys. A Mater. Sci. Process. 106, 295-307.

Morris, D., Beaumont, P.B., 1994. Portable Engravings at Springbok Oog and the Archaeological Contexts of Rock art of the Upper Karoo, South Africa. In: Dowson, T.A., Lewis-Williams, J.D. (Eds.), Contested Images: Diversity in Southern African Rock art Re-search. Witwatersrand University Press, Johannesburg, pp. 11-28. 
Olivares, M., Castro, K., Corchón, M.S., Gárate, D., Murelaga, X., Sarmiento, A., Etxebarria, N., 2013. Noninvasive portable instrumentation to study Palaeolithic rock paintings: the case of La Peña cave in San Roman de Candamo (Asturias, Spain). J. Archaeol. Sci. 40, 1354-1360.

Pearce, D.G., 2010. Conservation and management of collapsing rock paintings: three sites in Maclear District, Eastern Cape Province, South Africa. S. Afr. Archaeol. Bull. 65, 96-103.

Prinsloo, L.C., Barnard, W., Meiklejohn, I., Hall, K., 2008. The first Raman spectroscopic study of San rock art in the Ukhahlamba Drakensberg Park, South Africa. J. Raman Spectrosc. 39, 646-654.

Prinsloo, L.C., Tournié, A., Colomban, P., Paris, C., Bassett, S.T., 2013. In search of the optimum Raman/IR signatures of potential ingredients used in San/Bushman rock art paint. J. Archaeol. Sci. 40, 2981-2990.

Prinsloo, L.C., Wadley, L., Lombard, M., 2014. Infrared reflectance spectroscopy as an analytical technique for the study of residues on stone tools: potential and challenges. J. Archaeol. Sci. 41, 732-739.

Rifkin, R.F., 2012. Processing ochre in the Middle Stone Age: testing the inference of pre-historic behaviours from actualistically derived experimental data. J. Anthropol. Archaeol. 31, 174-195.

Rifkin, R.F., Haaland, M.M., Henshilwood, C.S., 2015. Late Pleistocene art mobilier from Apollo II Cave, Karas Region, southern Namibia. S. Afr. Archaeol. Bull. 70 (201), 113-123.

Rito, T., Richards, M.B., Fernandes, V., Alshamali, F., Cerny, V., Pereira, L., Soares, P., 2013. The first modern human dispersals across Africa. PLoS One http://dx.doi.org/10.1371/journal.pone.0080031.

Roldán, C., Villaverde, V., Ródenas, I., Novelli, F., Murcia, S., 2012. Preliminary analysis of Palaeolithic black pigments in plaquettes from the Parpalló cave (Gandía, Spain) carried out by means of non-destructive techniques. J. Archaeol. Sci. 40 (1), 744-754.

Rudner, I., 1983. Paints of the Khoisan rock artists. S. Afr. Archaeol. Soc. Goodwin Ser. 4, 14-20.

Texier, P.-J., Porraz, G., Parkington, J., Rigaud, J.-P., Poggenpoel, C., Tribolo, C., 2013. The context, form and significance of the MSA engraved ostrich eggshell collection from Diepkloof Rock Shelter, Western Cape, South Africa. J. Archaeol. Sci. 40, 3412-3431.

Thackeray, A.I., Thackeray, J.F., Beaumont, P.B., Vogel, J.C., 1981. Dated rock engravings from Wonderwerk Cave, South Africa. Science 214 (4516), 64-67.

Tournié, A., Prinsloo, L.C., Paris, C., Colomban, P., Smith, B., 2010. The first in situ Raman spectroscopic study of San rock art in South Africa: procedures and preliminary results. J. Raman Spectrosc. 42, 399-406.

Vanhaeren, M., d'Errico, F., Stringer, C., James, S.L., Todd, J.A., Mienis, H.K., 2006. Middle-Paleolithic shell beads in Israel and Algeria. Science 312, 1785-1788.

Villa, P., Soriano, S., Tsanova, T., Degano, I., Higham, T.F.G., d'Errico, F., Backwell, L., Lucejko, J.J., Colombini, M.P., Beaumont, P.B., 2012. Border Cave and the beginning of the Later Stone Age in South Africa. Proc. Natl. Acad. Sci. U. S. A. 109 (33), 13208-13213.

Villa, P., Pollarolo, L., Degano, I., Birolo, L., Pasero, M., Biagioni, C., Douka, K., Vinciguerra, R., Lucejko, J.J., Wadley, L., 2015. A Milk and Ochre Paint Mixture Used 49,000 Years ago at Sibudu, South Africa. PLoS One http://dx.doi.org/10.1371/journal.pone.0131273. 
Vogelsang, R., Richter, J., Jacobs, Z., Eichhorn, B., Linseele, V., Roberts, R.G., 2010. New excavations of Middle Stone Age deposits at Apollo 11 rock shelter, Namibia: stratigraphy, archaeology, chronology and past environments. J. Afr. Archaeol. 8 (2), 185-218.

Wendt, W.E., 1972. Preliminary report on an archaeological research programme in South West Africa. Cimbebasia (B) 2, 1-6.

Wendt, W.E., 1974. Art mobilier aus der Apollo 11-Grotte in Südwest-Afrika. Acta Praehist.Archaeol.5/6(5),142.

Wendt, W.E., 1976. Art mobilier from the Apollo 11 Cave, South West Africa: Africa's oldest dated works of art. S. Afr. Archaeol. Bull. 31 (121/122), 5-11.

Xu, B.T., Zhang, B., Kang, Y., Wang, Y.N., Li, Q., 2012. Applicability of CIELAB/CIEDE2000 formula in visual color assessments of metal ceramic restorations. J. Dent. 40, 3-9. 